\title{
New Urbanist Zoning for Dummies
}

Michael Lewyn

Touro Law Center, mlewyn@tourolaw.edu

Follow this and additional works at: https://digitalcommons.tourolaw.edu/scholarlyworks

Part of the Land Use Law Commons, Property Law and Real Estate Commons, and the State and Local Government Law Commons

\section{Recommended Citation}

58 Ala. L. Rev. 257 (2006)

This Article is brought to you for free and open access by the Faculty Scholarship at Digital Commons @ Touro Law Center. It has been accepted for inclusion in Scholarly Works by an authorized administrator of Digital Commons @ Touro Law Center. For more information, please contact Iross@tourolaw.edu. 


\section{HEINONLINE}

Citation: 58 Ala. L. Rev. 257 2006-2007

Content downloaded/printed from

HeinOnline (http://heinonline.org)

Mon Aug 15 15:15:37 2011

-- Your use of this HeinOnline PDF indicates your acceptance of HeinOnline's Terms and Conditions of the license agreement available at http://heinonline.org/HOL/License

-- The search text of this PDF is generated from uncorrected OCR text.

-- To obtain permission to use this article beyond the scope of your HeinOnline license, please use:

https://www.copyright.com/ccc/basicSearch.do?

\&operation $=$ go\&search Type $=0$

\&lastSearch $=$ simple\&all=on\&titleOrStdNo $=0002-4279$ 


\title{
NEW URBANIST ZONING FOR DUMMIES
}

\author{
Michael Lewyn
}

\section{INTRODUCTION}

For most of the twentieth century, American land use regulation sought to segregate land uses and to reduce population density, ${ }^{1}$ while American parking and street design regulation sought to facilitate driving by mandating wide streets ${ }^{2}$ and forcing landlords and businesses to build parking lots for their tenants and customers. ${ }^{3}$

These policies have combined to create a pattern of land use often described as "sprawl": low-density, automobile-oriented development. ${ }^{4}$ Where "single-use zoning"5 separates housing from commerce, and residential zones cover large amounts of thinly populated land, ${ }^{6}$ few people can live

* Assistant Professor, Florida Coastal School of Law. B.A., Wesleyan University; J.D., University of Pennsylvania Law School. I would like to thank David Fontana for his helpful comments and Shane Cralle for his research assistance. Any errors of fact, logic, or law are of course mine alone.

1. See Richard Briffault, Smart Growth and American Land Use Law, 21 ST. LouIS U. PUB. L. REV. 253, 253 (2002) ("[H]allmarks of American land use law . . . [include] reducing population density and dispersing residents over wider areas [as well as] the separation of different land uses from each other.") (emphasis omitted); see also Jerry Frug, The Geography of Community, 48 STAN. L. REV. 1047, 1091 (1996) ("[V]irtually all [current zoning laws] mandate the separation of different areas by function ....").

2. See Stephen H. Burrington, Restoring the Rule of Law and Respect for Communities in Transportation, 5 N.Y.U. ENVTL. L.J. 691, 694 (1996) (noting because transportation agencies generally "treat streets and roads simply as conduits for motor vehicle traffic," they generally favor wide streets regardless of consequences for nondrivers); Oliver A. Pollard, III, Smart Growth and Sustainable Transportation: Can We Get There From Here?, 29 FORDHAM URB. L.J. 1529, 1534 (2002) (explaining that street design standards often "mandate the construction of unnecessarily wide roads with high speed limits").

3. Pollard, supra note 2, at 1534 ("[L]ocal governments often adopt minimum parking requirements that mandate substantial free parking, encouraging people to drive more . ...").

4. See Oliver Gillham, The Limitless City: A Primer on the Urban Sprawl Debate 8 (2002) (noting characteristics of sprawl include "low density, separated land uses [and] automobile dominance," as well as "leapfrog patterns of development" and "a minimum of public open space"); $c f$. infra notes 5-7, 164, 192-194 and accompanying text (explaining how low density and segregation of uses lead to automobile dominance). For the purposes of this Article, "sprawl" is defined in the main text. I note, however, that other definitions of sprawl focus on the location of real estate development (that is, the movement of population from cities to suburbs) as opposed to the automobile-dependent nature of such development. See, e.g., William W. Buzbee, Urban Sprawl, Federalism, and the Problem of Institutional Complexity, 68 FORDHAM L. REV. 57, 63 (1999) (asserting that sprawl occurs when an urban area "expands in an outward sprawling pattern, usually encompassing a multiplicity of local governments").

5. See Terry J. Tondro, Sprawl and Its Enemies: An Introductory Discussion of Two Cities' Efforts to Control Sprawl, 34 CONN. L. REv. 511, 514 (2002) ("[S]ingle use zoning [is] the designation of separate land areas for different uses.").

6. See Jonathan Barnett, New Urbanism and Codes, in CODIFYING NEW URBANISM 1, 3 (Congress for the New Urbanism ed., 2004) (describing "mapping of [single-use] zones over big areas" as "a big 
within walking distance of commercial zones. ${ }^{7}$ Where wide streets speed up motor vehicle traffic, walking is unpleasant and perhaps even dangerous. ${ }^{8}$ And where parking lots surround buildings, pedestrians must walk through a sea of parking in order to reach those buildings, making pedestrian commutes longer and more unpleasant. ${ }^{9}$

Over the past two decades, a group of architects generally known as the "New Urbanist" movement has sought to design more pedestrian-friendly neighborhoods. ${ }^{10}$ New Urbanists argue that:

*Automobile-dependent sprawl reduces individual freedom by immobilizing Americans too young or too old to drive. ${ }^{11}$

*Sprawling development increases driving, which in turn has led to increased traffic congestion ${ }^{12}$ and pollution. ${ }^{13}$

part of the recipe for suburban sprawl").

7. See Andres Duany \& Emily Talen, Making the Good Easy: The Smart Code Alternative, 29 FORDHAM URB. L.J. 1445, 1447 (2002) (explaining that in neighborhoods organized around "the mobility pattern of the pedestrian," most residents should live no more than a quarter of a mile from stores and schools); Chad Lamer, Why Government Policies Encourage Urban Sprawl and the Alternatives Offered by New Urbanism, 13 KAN. J.L. \& PUB. POL'Y 391, 396 (2004) (noting that, by contrast, in low-density areas, "the use of an automobile is almost a necessity because daily needs are outside of walking or biking distance"). Moreover, residents of low-density zones often cannot even use public transportation to reach commercial zones because low density reduces the number of people who can live within walking distance of a transit stop or station. See Robert H. Freilich, The Land-Use Implications of TransitOriented Development: Controlling the Demand Side of Transportation Congestion and Urban Sprawl, 30 URB. LAW. 547, 552 n.18 (1998) (asserting that commuters generally will not walk more than a quarter of a mile to a transit station, and thus "residential densities of at least 7-15 dwelling units per acre are needed in order to encourage the utilization of public transit"); Lamer, supra, at 396 (explaining most "sprawl" residential developments have five or fewer dwellings per acre). But $c f$. JONATHAN LEVINE, ZONED OUT: REGULATION, MARKETS, AND ChOICES IN TRANSPORTATION AND METROPOLITAN LANDUSE 4 (2006) (noting that the strength of relationship between land use and travel pattems "has resisted precise quantification").

8. See ANDres Duany et al., Suburban Nation: The Rise of Sprawl and the Decline of THE AMERICAN DREAM 64-83 (2001) (describing typical American streets as "unpleasant," "dangerous," and "boring"); Burrington, supra note 2, at 704 (noting that the possibility of a pedestrian being killed if struck by a car is $3.5 \%$ if the car is traveling 15 miles per hour and $83 \%$ if the car is traveling at 44 miles per hour).

9. See Amy Sutherland, Push For 'New Urbanism': Most Neighborhoods and Downtowns Seem to Discourage Spontaneous Human Interaction, PORTLAND PRESS HERALD, Jan. 1, 1998, at 1A, available at 1998 WLNR 5763795 (pointing out that where buildings are set back from the street and pedestrians have to walk through a parking lot to reach buildings, the landscape seems "vast" and "unfriendly looking").

10. See GLLHAM, supra note 4, at 180-81 (explaining that the New Urbanist movement began in "1980s with a small group of architects"); Ray Gindroz, City Life and New Urbanism, 29 FordHAM URB. L.J. 1419, 1429 (2002) (noting that the Congress for the New Urbanism now has 2,000 members from a variety of disciplines); Brian W. Ohm \& Robert J. Sitkowski, The Influence of New Urbanism on Local Ordinances: The Twilight of Zoning?, 35 URB. LAW. 783, 784 (2003) (noting that the Congress for the New Urbanism is "the main advocacy organization for new urbanism").

11. See DUANY ET AL., supra note 8, at 116 (pointing out that the inability to walk to most activities means that "a child's personal mobility extends no farther than the edge of [his or her] subdivision"); id. at 123 (noting automobile dependency puts nondriving elderly "out of reach of their physical and social needs"); $c f$. Jeff Plungis \& Nick Bunkley, Innovations May Keep Seniors Safer on Road, DETROIT NEws, Mar. 14, 2005, at A1, available at http://www.detnews.com/2005/specialreport/0503/14/A01 $116287 . \mathrm{htm}$ ("[Twenty-one] percent of Americans over 65 no longer drive. Within the non-driving population, 54 percent stay home on any given day because they don't have a viable transportation option.").

12. See CONGRess for tHE New URBAnISM, THE COMING Demand 7 (2001), available at www.cnu.org/cnu_reports/Coming_Demand.pdf (explaining that as long as Americans "keep living in 
*"Sprawl is ugly, produc[ing] nothing in the public realm worthy of aesthetic contemplation ....."14

*Pedestrian-friendly communities might improve public health by allowing their residents to get more exercise. ${ }^{15}$

*Pedestrian-friendly neighborhoods, unlike sprawling subdivisions, foster community by encouraging chance meetings between their residents. ${ }^{16}$

*Sprawling development consumes more land than more compact development, thus reducing the supply of farmland, open space, and wildlife habitat. ${ }^{17}$

The New Urbanist remedy is to build Traditional ${ }^{18}$ Neighborhood Developments (TNDs) ${ }^{19}$ - neighborhoods with streets narrow enough for pedestrians to safely $\operatorname{cross}^{20}$ and with housing within walking distance of schools, workplaces, shops, and other human activities. ${ }^{21}$

TNDs often conflict with conventional zoning and street design regulations. ${ }^{22}$ While New Urbanists seek to build mixed-use, compact neighborhoods, ${ }^{23}$ conventional land use regulation favors single-use, low-density sprawl. ${ }^{24}$ Developers have occasionally been able to build TNDs by obtaining exemptions from zoning codes-but nevertheless, conventional, auto-

ever more sprawling subdivisions" auto use, and by implication congestion, will continue to grow); id. at 2 (asserting that more walkable neighborhoods "reduce overall traffic").

13. See William W. Buzbee, Sprawl's Political-Economy and the Case for a Metropolitan Green Space Initiative, 32 URB. LAW. 367, 379 (2000) ("[New Urbanism] can by reducing car dependence reduce air pollution....").

14. Phillip Bess, The New Urbanism: Friend or Foe of Property Rights?, ThE Claremont INSTITUTE FOR THE STUDY OF STATESMANSHIP AND POLITICAL PHILOSOPHY, Feb. 8, 2005, http:// www.claremont.org/projects/local_gov/essays/prconfbess.html. Numerous pictures of "ugly" sprawl can be found within the Bess article, id., and in DUANY ET AL., supra note 8, at 25-26, 28-30, 41, 43, 47.

15. See Congress for the New Urbanism, Frequently Asked Questions, http://www.cnu.org /about/disp_faq.html (last visited Nov. 11, 2006) ("It's not that walkable neighborhoods make you thin, but they provide an environment where everyday activity is facilitated. That means that some people are going to get more exercise than they would otherwise. Those people are likely to end up healthier.").

16. See Sutherland, supra note 9 ("[Sprawl] discourage[s] spontaneous human interaction. . . . [However, walkable areas] foster a sense of community.").

17. See GillhaM, supra note 4 , at 75,77 .

18. New Urbanists use the term "traditional" because such developments follow the pre-World War II American tradition of mixed-use, pedestrian-friendly development. See DUANY ET AL., supra note 8, at 3-4 (pointing out that before World War II, most American settlements were "mixed-use, pedestrianfriendly communities" and accordingly characterizing such neighborhoods as "traditional").

19. New Urbanists sometimes use the terms "New Urbanism" and "TND" interchangeably, and this Article will do the same. See, e.g., The Town Paper, TND Neighborhoods, http://www.tndtownpaper .com/neighborhoods.htm (last visited Nov. 11, 2006). But see GILLHAM, supra note 4, at 181-84 (dividing New Urbanist developments into TNDs and "transit-oriented developments"; the latter is organized around mass transit station, while the former need not be).

20. See Frug, supra note 1, at 1091 ("[P]edestrians "want narrow streets . . . [rather than] six-lane arterials." (quoting PETER CALTHORPE, THE NEW AMERICAN METROPOLIS: ECOLOGY, COMMUNITY, AND THE AMERICAN DREAM 27 (1993))).

21. Id. ("New [U]rbanists ... [seek to create] 'neighborhoods of housing, parks, and schools placed within walking distance of shops, civic services, jobs, and transit."' (quoting CALTHORPE, supra note 20, at 16)).

22. See id. at 1093 (noting that New Urbanism is illegal under many zoning codes).

23. Id. at 1091 (pointing out that New Urbanists favor "multi-use environments").

24. See infra Part III.B (discussing conventional zoning and its effects). 
mobile-oriented subdivisions are far easier to build than TNDs under existing land use law. ${ }^{25}$

Because existing zoning is so hostile to New Urbanism, New Urbanists have begun to develop alternative zoning codes codifying New Urbanist principles. ${ }^{26}$ Most such ordinances do not seek to regulate an entire municipality but instead merely to add a "traditional neighborhood" zone to a municipality's menu of zones. ${ }^{27}$ However, Duany Plater-Zyberk \& Company (DPZ), a leading New Urbanist architectural firm, ${ }^{28}$ has drafted a broader code known as the "SmartCode,", which may be used as a comprehensive alternative to conventional zoning ordinances rather than a supplement to those ordinances. ${ }^{30}$ New Urbanist codes have been criticized by some property rights advocates, who assert that such codes are overly restrictive. ${ }^{31}$

The purpose of this Article is to compare New Urbanist zoning to sprawl-oriented conventional zoning, using the SmartCode and two conventional zoning codes as case studies. Specifically:

*Part II of the Article sets forth a brief history of American land use regulation and of the New Urbanist response to the status quo.

*Part III compares conventional sprawl-producing land use regulations to SmartCode provisions addressing the same issues as those regulations and explains how the SmartCode is both more pedestrian-friendly ${ }^{32}$ and, as Part IV illustrates, more protective of property rights (and thus more constitutionally sound) than conventional codes.

25. See infra notes 107-125 and accompanying text (explaining deficiencies of other legal strategies for allowing TNDs).

26. See generally Ohm \& Sitkowski, supra note 10, at 786-88 (describing New Urbanist codes).

27. See id. at 789 ("A more common [New Urbanist] approach . . . is the addition of new urbanist development to the menu of development options available in their zoning ordinances.").

28. Id. at 790 (describing the firm as "one of the leading firms in the new urbanism movement"); see also Duany Plater-Zyberk \& Co., http://www.dpz.com (last visited Nov. 11, 2006).

29. See DUANY, PlATER-ZYBERK \& CO., SMARTCODE ANNOTATED, hitp://placemakers.com /SmartCode/3000-02-Annotated_8.0.pdf (last visited Nov. 11, 2006) [hereinafter SMARTCODE]; Maricé Chael, The SmartCode: A Weapon to Fight the Sprawl War, THE TOWN PAPER, Spring 2003, available at http://www.tndtownpaper.com/Volume5/SmartCode.htm (noting that DPZ authored SmartCode).

30. But it does not need to be. A municipality may enact both the SmartCode and a conventional zoning ordinance and allow developers to choose between the two. See SMARTCODE, supra note 29, art. 3.1.1 ("Existing [1]ocal [c]odes also shall remain available by right."); id. (explaining that if a city retains both codes, "[a] developer may elect to proceed under Article 3 . . . or use the existing zoning ordinance" but may not create "a disappointing hybrid community" by mixing the two codes). I note in passing that, throughout this Article, I shall use section and table numbers to refer to the actual requirements of the SmartCode and page numbers to refer to the comments appended by the drafters to those provisions.

31. See, e.g., LEVINE, supra note 7, at 11 (noting Ronald Utt of the Heritage Foundation characterizes New Urbanism as an attempt to "simply force people to live" in more urban environments (quoting Eli Lehrer, Burbsprawl: Room to be Free?, INSIGHT ON THE NEwS, Nov. 23, 1998, http://www. findarticles.com/p/articles/mi_m1571/is_43_14/ai_55710738) (internal quotation marks omitted)); Chris Fiscelli, Reason Public Policy Institute, Zoning Needs an Overhaul (Sept. 8, 2003), http://www.rppi.org /zoning.shtml ("[New Urbanist codes] carry the danger of over-regulation and defining specific outcomes.").

32. Thus, this Article is not meant to compare every single SmartCode provision with conventional zoning and subdivision regulations. Instead, the Article focuses on conventional regulations, which mandate sprawl and encourage automobile-dependent development, and on SmartCode provisions that are comparable to those regulations. 
*Part V explains how the SmartCode could be made even more protective of both property rights and the SmartCode's goal of promoting walkable communities.

\section{FIRST, A LITTLE BACKGROUND . . .}

Once upon a time, government regulated land use far less than it does today. But as government began to regulate land use more heavily, municipalities began to use their regulatory powers to favor single-use, low-density zoning and automobile-oriented street design.

\section{A. A Brief History of Zoning}

Even in the nineteenth century, government occasionally regulated land use. Cities limited the height of buildings, regulated polluting industries, ${ }^{33}$ and enacted a variety of other ad hoc regulations. ${ }^{34}$ In addition, courts limited landowners' powers through nuisance ${ }^{35}$ and contract law. ${ }^{36}$ But zoning in its current form was nonexistent. ${ }^{37}$

But in the early twentieth century, a broad coalition of interests sought to impose additional regulations upon landowners. Architectural reformers sought to regulate land use in order to make cities more aesthetically appealing. ${ }^{38}$ Social reformers claimed that zoning would alleviate the misery of the urban poor by keeping working-class Americans far away from polluting factories. ${ }^{39}$ Retailers catering to upper-income clients wanted to be far away from factories full of working-class immigrant employees, ${ }^{40}$ and up-

33. See Eric R. Claeys, Euclid Lives? The Uneasy Legacy of Progressivism in Zoning, 73 FORDHAM L. REv. 731, 737 (2004); Erin Ryan, Student Article, Zoning, Taking, and Dealing: The Problems and Promise of Bargaining in Land Use Planning Conflicts, 7 HARV. NegOT. L. Rev. 337, $341-42$ (2002) (listing numerous examples of nineteenth century antipollution regulations).

34. Ryan, supra note 33, at 342 (noting that local ordinances sometimes targeted offensive but nonpolluting land uses such as sale of alcohol).

35. See Garland Coal \& Mining Co. v. Few, 267 F.2d 785, 789-90 (10th Cir. 1959) ("Under the common law a private nuisance arose from the unwarrantable, unreasonable or unlawful use by a person of his own property to the injury of another.").

36. See Andrew Auchincloss Lundgren, Beyond Zoning: Dynamic Land Use Planning in the Age of Sprawl, 11 BUFF. ENVTL. L.J. 101, 115, 117 (2004) (explaining that even before zoning laws were created, landowners could voluntarily limit their rights by contract).

37. See ROBERT C. ELLICKSON \& VICKI L. BEEN, LAND USE CONTROLS: CASES AND MATERIALS 87 (2d ed. 2000) (noting that the first American zoning ordinance was Los Angeles's 1909 law); infra note 42 and accompanying text (describing Los Angeles's system).

38. See Charles M. Haar, Reflections on Euclid: Social Contract and Private Purpose, in ZoNING AND THE AMERICAN DREAM: PROMISEs Still to KeEP 333, 339 (Charles M. Haar \& Jerold S. Kayden eds., 1989) [hereinafter ZONING AND THE AMERICAN DREAM] (explaining that advocates of "City Beautiful" movement sought "purposeful intervention of government to achieve urban beautification").

39. Id. at 339-40 (explaining that "a ragtag grouping of idealists and special interest groups" believed that zoning would allow the poor to live amid "plenitudes of fresh air and sunlight" by "keeping industry and trade from residential sections").

40. See Harold A. McDougall, Regional Contribution Agreements: Compensation for Exclusionary Zoning, 60 TEMP. L. REV. 665, $673 \mathrm{n} .63$ (1987) (noting that where factories were close to high-end retailing, factories' immigrant workers "would cluster in the streets at lunchtime, creating an atmosphere that the retailers felt was not conducive to business with upper-status clientele"). 
per-income homeowners wanted to be far away from lower-income homeowners. ${ }^{41}$

In 1909, Los Angeles became the first major American city to enact a zoning ordinance, dividing the city into one residential district and seven industrial districts. ${ }^{42}$ In 1916, New York enacted a somewhat more complex zoning ordinance, with a residence district, four retail districts, two business districts, one manufacturing district, and an unrestricted district allowing all uses. ${ }^{43}$ And in addition to dividing the city into districts, New York's ordinance limited density by limiting the size of commercial buildings. ${ }^{44}$

Zoning quickly spread throughout America. By 1920, 904 cities had zoning ordinances, ${ }^{45}$ including 82 of the 93 American cities with over 100,000 people. ${ }^{46}$ Later in the 1920 s, the Federal Department of Commerce drafted a model Standard State Zoning Enabling Act (SSZEA), ${ }^{47}$ which most states have adopted in some form. ${ }^{48}$ SSZEA granted cities the power to restrict building size and height, the size of yards and other open spaces, the density of population, and the location and use of buildings. ${ }^{49}$ SSZEA declared that such legislation would be designed "to prevent the overcrowding of land [and] to avoid undue concentration of population." ${ }^{\text {" }}$ Thus, even the earliest zoning laws were designed to make cities less compact.

The courts have been highly deferential to the sort of zoning contemplated by SSZEA. In the 1926 case of Village of Euclid v. Ambler Realty Co., ${ }^{51}$ the Supreme Court upheld a municipal ordinance creating six zones, ${ }^{52}$ one of which was devoted primarily to single-family houses. ${ }^{53}$ The Court ruled that zoning ordinances generally are constitutional unless "arbi-

41. See Michael Allan Wolf, The Prescience and Centrality of Euclid v. Ambler, in ZONING AND THE AMERICAN DREAM, supra note 38 , at 252, 258-59.

42. See ELLICKSON \& BEEN, supra note 37, at 87 (noting Los Angeles as the first American city to adopt zoning); Ryan, supra note 33, at 342 (describing details of Los Angeles's system).

43. See Michael Kwartler, Legislating Aesthetics: The Role of Zoning in Designing Cities, in ZONING AND THE AMERICAN DREAM, supra note 38, at 187, 190.

44. See Georgette C. Poindexter, Light, Air, or Manhattanization?: Communal Aesthetics in Zoning Central City Real Estate Development, 78 B.U. L. REv. 445, 461-63 (1998) (describing New York's density limits in detail).

45. See Joe R. Feagin, Arenas of Conflict: Zoning and Land Use Reform in Critical PoliticalEconomic Perspective, in ZONING AND THE AMERICAN DREAM, supra note 38, at 73, 81 .

46. Id. at 82 .

47. See ADVISORY COMM. ON ZONING, U.S. DEP'T OF COMMERCE, A STANDARD STATE ZONING ENABLING ACT (rev. ed. 1926), http://www.planning.org/growingsmart/pdf/SZEnablingAct 1926.pdf.

48. Thomas B. Griffen, Note, Zoning Away the Evils of Alcohol, 61 S. CAL. L. Rev. 1373, 1383 (1988); see also DANIEL R. MANDELKER ET AL., STATE AND LOCAL GOVERNMENT IN A FEDERAL SYSTEM: CASES AND MATERIALS 202-03 (4th ed. 1996) (noting that some states later amended their zoning enabling statutes and quoting a New Jersey statute that differs from SSZEA primarily by adding additional details).

49. ADVISORY COMM. ON ZONING, supra note $47, \S 1$.

50. Id. \&3.

51. 272 U.S. 365 (1926).

52. Id. at 397, 380-81. The ordinance also restricted building heights and lot sizes. Id. at 381-82. However, the Court did not discuss the constitutionality of these restrictions in detail.

53. Id. at 380 . Public parks, water towers and reservoirs, railway stations, farms, and certain agriculture-related business were also allowed in this zone. Id. 
trary and unreasonable" ${ }^{\mathrm{54}}$ and that Euclid's segregation of single-family houses from commerce (and even from apartment houses) was constitutional under this test. ${ }^{55}$

After Euclid, single-use zoning ${ }^{56}$ (also known as "Euclidean zoning" after the case which upheld that technique $)^{57}$ became virtually universal. ${ }^{58}$ Courts have upheld not only the segregation of uses endorsed by the Euclid Court, but also regulations limiting density, such as municipal ordinances setting forth minimum lot sizes for houses, ${ }^{59}$ requiring buildings to be set back from streets, ${ }^{60}$ and requiring landowners to set aside land for parking lots. ${ }^{61}$

In recent decades, zoning law has become even more intrusive. According to one survey of town planners and engineers, $70 \%$ of municipalities made their zoning rules more restrictive between 1997 and $2002,{ }^{62}$ while only $16 \%$ reduced landowners' regulatory burdens. ${ }^{63}$ Compact, pedestrianoriented development is especially vulnerable to regulatory attack. The Urban Land Institute (ULI) (a developers' trade association) ${ }^{64}$ conducted a 2001 survey asking developers about the impact of zoning upon "alternatives to conventional, low-density, automobile-oriented, suburban development." ${ }^{, 65}$ Of the developers surveyed, $85.4 \%$ agreed that the supply of such development was inadequate to meet market demand, ${ }^{66}$ and $78.2 \%$ identified government regulation as a significant barrier to such development. ${ }^{67}$ The ULI survey also revealed that over $60 \%$ of developers in cities and in-

54. Id. at 395.

55. Id. at 391-95.

56. See Tondro, supra note 5 , at $\mathbf{5 1 4}$ (defining term).

57. See Nicole Stelle Gamett, Ordering (And Order in) the City, 57 STAN. L. REV. 1, 4 (2004) ("Euclidean zoning [is zoning based on the] value judgment that the appropriate way to order different land uses is to separate them from one another into single-use zones.") (emphasis added).

58. See Frug, supra note 1, at 1091 (pointing out that segregation of land uses is virtually universal in United States).

59. See Agins v. City of Tiburon, 447 U.S. 255 (1980), abrogated by Lingle v. Chevron U.S.A., Inc., 544 U.S. 528 (2005).

60. See Gorieb v. Fox, 274 U.S. 603 (1927).

61. See Stroud v. City of Aspen, 532 P.2d 720 (Colo. 1975).

62. See Eran Ben-Joseph, Facing Subdivision Regulations, in REGUlating PLACE: STANDARDS AND THE SHAPING OF URBAN AMERICA 167, 180 (Eran Ben-Joseph \& Terry S. Szold eds., 2005).

63. Id. The survey was conducted in 2002 , id. at $184 \mathrm{n} .8$, and asked about changes in the preceding five years, $i d$. at 180; see also LEVINE, supra note 7 , at 78 (noting that territory zoned for single-family homes is almost never rezoned for other uses; for example, between 1970 and 1999 less than $1 \%$ of Massachusetts land was rezoned from single-family use to other uses).

64. LEVINE, supra note 7, at 125 (describing ULI as "the premiere national organization of land developers").

65. Id. at 126 .

66. See id. at 128 tbl.7-4. This group was divided between $66.8 \%$ who believed that there was generally not enough compact development to meet consumer demand and an additional $18.6 \%$ who responded that the supply of such development was high enough to meet consumer demand-but not in the "right locations" (presumably meaning the neighborhoods where consumer demand for compact development was highest). Id.

67. Id. at 129 tbl.7-5. By contrast, only $35.3 \%$ invoked financing as an obstacle to more compact development, and only $26.3 \%$ listed inadequate consumer demand. Id. Thus, it cannot plausibly be argued that pedestrian-friendly development is rare solely because of lack of market demand. 
ner suburbs stated that they wished to build more compact development than was generally allowed by government regulation. ${ }^{68}$

\section{B. A Brief History of Street Design and Parking Regulation}

In 1880, fewer than half of American streets were paved, ${ }^{69}$ and streets were often privately maintained and financed. ${ }^{70}$ But in the late nineteenth and early twentieth centuries, a wide range of groups affiliated with the bicycle and auto industries lobbied for new streets with more pavement. ${ }^{71}$ In response to such lobbying, local governments paved nearly every urban street in America by 1924, ${ }^{72}$ sometimes with federal assistance. ${ }^{73}$

In 1934, the federal government created the Federal Housing Administration (FHA) - an agency that subsidized home ownership by insuring private sector loans-but only for homes that met FHA standards. ${ }^{74}$ These standards prohibited gridded streets ${ }^{75}$ in residential neighborhoods, instead describing cul-de-sacs ${ }^{76}$ as "the most attractive form for family dwellings." 77 The FHA also recommended residential streets that were twentyfour to twenty-six feet wide ${ }^{78}$-about $50 \%$ larger than some older streets. ${ }^{79}$ FHA standards also required long blocks ${ }^{80}$ and low densities. ${ }^{81}$ Because the

68. Id. at 131 fig.7-1. In particular, about $80 \%$ of developers indicated that they would develop more compactly in inner suburbs if zoning was less burdensome, and over $60 \%$ similarly indicated that relaxed regulations would lead them to develop more densely in central cities. Id. By contrast, developers in rural areas were less interested in more compact development. See id.

69. Eric A. Cesnik, The American Street, 33 URB. LAw. 147, 163 (2001).

70. See id. at 167 (noting that during the late nineteenth and early twentieth centuries, decisions related to streets and their financing shifted from individual landowners to centralized city government); see also Michael Southworth \& Eran Ben-Joseph, Street Standards and the Shaping of Suburbia, $61 \mathrm{~J}$. AM. PLAN. ASS'N 65, 66-67 (1995), available at 1995 WLNR 3951363 (describing examples of nineteenth century private street design).

71. See Cesnik, supra note 69, at 167 (describing how bicyclists lobbied for paved streets in the nineteenth century and how, by the 1920 s, tire manufacturers and dealers, auto parts suppliers, oil companies, service station owners, road builders, and land developers had also begun to lobby for new roads).

72. Id. at 163 .

73. See id. at 171 (noting that Congress funded state and local road building beginning in 1916).

74. See GillHAM, supra note 4, at 37; Southworth \& Ben-Joseph, supra note 70, at 74 .

75. Southworth \& Ben-Joseph, supra note 70 , at 74. A grid street pattern is one that resembles a network of criss-crossing parallel bars. See Merriam-Webster Online Dictionary, http://www.mw.com/dictionary/grid (last visited Nov. 11, 2006) (defining "grid" as "a network of uniformly spaced horizontal and perpendicular lines").

76. A cul-de-sac is a lollipop-shaped dead-end street. See DUANY ET AL., supra note 8, at 34.

77. See Michael Southworth \& Eran Ben-Joseph, Regulated Streets: The Evolution of Standards for Suburban Residential Streets 35 (Inst. of Urban and Reg'l Dev., Working Paper No. 593, 1993).

78. Id. at 35-36. By "street width," I mean the width of pavement (that is, travel lanes for vehicles) as opposed to the total right-of-way width, which includes space for sidewalks and vegetation. See id. at 35 (noting that right-of-way not used for pavement devoted to such uses).

79. See id. at 19 fig.8b, 26 fig.10b (showing examples of streets with sixteen to eighteen feet of pavement).

80. Compare id. at 34 (explaining that standards dictated that "[b]locks should generally range from 600 feet to 1,000 feet in length"), with REID EwING, PEDESTRIAN- AND TRANSIT-FRIENDLY DESIGN: A PRIMER FOR SMART GROWTH 4, http://www.epa.gov/smartgrowth/pdf/ptfd_primer.pdf (last visited Nov. 11,2006 ) (arguing pedestrian-friendly development requires blocks no longer than 300 feet).

81. See Southworth \& Ben-Joseph, supra note 77 , at 34 (noting that FHA regulations require de- 
majority of American mortgages were FHA-insured, the FHA minimum standards governed most new development. ${ }^{82}$ And local governments generally adopted rules based on FHA standards, which meant that even homes not insured by the FHA were governed by FHA rules. ${ }^{83}$

More recently, traffic engineers have been influential in determining street size and design. In 1914, state and local highway officials founded the American Association of State Highway and Transportation Officials (AASHTO) ${ }^{84}$ Over the past several decades, AASHTO has issued guidelines for major streets. ${ }^{85}$ In the 1950 s, AASHTO proposed that arterial streets (that is, the streets with the highest traffic volumes) ${ }^{86}$ have at least six to eight lanes, ${ }^{87}$ each of which should be at least twelve feet wide. ${ }^{88}$ Thus, AASHTO effectively urged that arterials include seventy-two to ninety-six feet of pavement. In addition, AASHTO recommended that such streets should typically be about 1,000 feet long in order to minimize the number of intersections ${ }^{89}$ and that on-street parking be banned from arterial streets. ${ }^{90}$ AASHTO guidelines, like those of ITE and FHA, have generally been adopted by local governments. ${ }^{91}$

tached homes to sit on a lot of at least 6,000 square feet).

82. Id. at 33 ("By 1959 FHA mortgage insurance had helped . . [t]hree out of every five American families . . to purchase a home.").

83. See id. at 39 (noting that local subdivision regulations are typically "adopted from the Federal Government's established criteria, in particular those of the FHA").

84. See Jay S. Bybee, Advising the President: Separation of Powers and the Federal Advisory Committee Act, 104 YALE L.J. 51, 84 n.172 (1994).

85. See FED. Highway AdMIN., U.S. DEP'T OF TRANSP., FHWA Highway Functional CLASSIFICATION GUIDELINES II-1 (1989), http://www.fhwa.dot.gov/planning/fcsec2_1.htm [hereinafter FHWA GUIDELINES].

86. See id. at II-1 (explaining that arterials are "the highest traffic volume corridors"). These streets are generally dominated by businesses rather than residences. See id. (noting that smaller arterials "may carry local bus routes . . . but ideally should not penetrate identifiable neighborhoods[,]" while the largest arterials are limited-access highways). Arterials generally intersect with "collector" streets, which serve both residential and commercial areas. Id. In turn, collector streets serve "local" streets devoted primarily to residential use. Id.

87. See AM. Ass'N Of State highway Officials, A Policy on ARTERIal Highways in URBan AREAS 208 (1957) [hereinafter AASHO POLICY 1957] ("[Six] to 8 lanes for through traffic represents an optimum major street. With more than 6 lanes there may be confusion and interference at cross streets."). However, more recent guidelines have been somewhat more flexible on this issue. Compare id., with

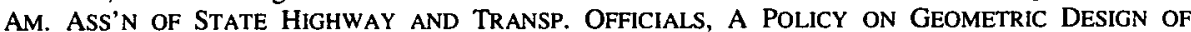
HIGHWAYS AND STREETS 477 (2001) [hereinafter AASHTO POLICY 2001] (explaining that the normal size of arterials is "four to eight lanes"). Because many streets were built under AASHTO's older guidelines, those guidelines are still quite influential. See DUANY ET AL., supra note 8, at 7-8 (noting that many suburbs were built in decades after World War II).

88. See AASHO POLICY 1957, supra note 87, at 204 ("Lane widths on major streets normally should be not less than 11 feet and desirably not less than 12 feet."); see also AASHTO POLICY 2001, supra note 87, at 476 (noting that 12 feet is the "most desirable" width). But cf. infra notes 286-294 and accompanying text (explaining disadvantages of wide streets).

89. See AASHO POLICY 1957, supra note 87 , at 70 ("Continuous through traffic operation as desired . . cannot be obtained unless the spacing of cross streets is about 1,000 feet or more.").

90. Id. at 204; see also AASHTO POLICY 2001, supra note 87, at 482 (asserting parking is "highly undesirable" on arterials). But cf. infra notes 251-252 and accompanying text (discussing advantages of on-street parking).

91. See Burrington, supra note 2, at 694 (describing AASHTO publications as "the bible of conventional street and road design"). In fact, until 1991 the federal government required use of AASHTO designs for use in federally funded road projects. Id. at 728. Even today, most state and local govern- 


\section{The New Urbanist Insurgency}

During the 1980 s, a group of young architects began to build more pedestrian-oriented neighborhoods. In 1982, DPZ began to build the first highly publicized TND: Seaside, a resort town in the Florida Panhandle. ${ }^{92}$ Throughout the 1980s, DPZ and other architects with similar ideas continued to create TNDs, mostly in small-city downtowns. ${ }^{93}$

In 1991, a group of architects, planners, and developers met to create the "Ahwahnee Principles," 94 a document proposing that communities "be designed so that housing, jobs, daily needs and other activities are within easy walking distance of each other"95 and that streets "should encourage pedestrian and bicycle use by . . discouraging high speed traffic.",96

Two years later, another group of architects formed the Congress for the New Urbanism (CNU). ${ }^{97}$ The CNU Charter asserts that neighborhoods should be "compact, pedestrian-friendly, and mixed use" and that neighborhood activities "should occur within walking distance [of housing], allowing independence to those who do not drive, especially the elderly and the young." "Streets should be set in "[i]nterconnected networks . . . to encourage walking" 100 and "should be safe, comfortable, and interesting to the pedestrian." 101

Over 500 TNDs have been built in cities and suburbs throughout the United States, ${ }^{102}$ and CNU now has over 2,000 members. ${ }^{103}$ The market for

ments rely on AASHTO guidelines. Id. at 729 .

92. See GLlhAM, supra note 4, at 181 (describing Seaside as one of the "[p]ioneering efforts" of New Urbanism and noting that its planning began in 1982); Gindroz, supra note 10, at 1425 (describing Seaside).

93. See Jean Scott, Congress for the New Urbanism, Florida Chapter, An Overview of New Urbanism in South Florida, http://www.cnuflorida.org/nu_florida/south_florida.htm (last visited Nov. 11, 2006) (describing New Urbanist-influenced redevelopment projects in several Florida downtowns).

94. This document was named for the Ahwahnee Lodge in Yosemite National Park, where the document's drafters met. See Sutherland, supra note 9.

95. Local Government Commission, Ahwahnee Principles for Resource-Efficient Communities, www.lgc.org/ahwahnee/principles.html (last visited Nov. 4, 2006) [hereinafter Ahwahnee Principles].

96. Id.

97. See Congress for the New Urbanism, CNU History, http://cnu.org/aboutcnu (follow "History" hyperlink) (last visited Nov. 11, 2006) (noting that $\mathrm{CNU}$ "was founded . . . by a group of enthusiastic architects" and that its first annual "Congress" in 1993 had 100 attendees).

98. DUANY ET AL., supra note 8, at 263.

99. Id.

100. Id.; see also id. at 23, 34 (noting that cul-de-sacs create traffic congestion by forcing all traffic upon a single road and also create an "utterly disorienting" environment); Frug, supra note 1, at 1091 (emphasizing that interconnected streets facilitate walking within a neighborhood, while cul-de-sac streets require residents to go through major streets in order to enter nearby residential streets).

101. DUANY ET AL., supra note 8, at 264 (quoting CNU charter). Both the CNU Charter and the Ahwahnee Principles address a variety of other issues as well, such as transportation, historic preservation, and economic diversity. See id; Ahwahnee Principles, supra note 95. However, this Article focuses primarily on the differences between New Urbanism and conventional zoning and in particular, to differences most relevant to the pedestrian-friendliness of development.

102. See Jim Cariton, It Takes A Village to Lure Buyers Back to Town, WALL ST. J., Mar. 8, 2006, at BI (noting that these communities have been built in both cities and suburbs and that they contain "tens of thousands of homes").

103. Gindroz, supra note 10 , at 1429 ("[CNU] has more than 2000 members from disciplines includ- 
these projects has been brisk; consumers have been willing to pay a premium for TND housing. ${ }^{104}$

\section{Zoning for New Urbanism}

TNDs often violate Euclidean zoning $\operatorname{codes}^{105}$ because those codes generally segregate residences from commerce and mandate low density, while New Urbanists favor compact neighborhoods where residents can walk from their homes to jobs and stores. ${ }^{106}$ New Urbanists have proposed a variety of solutions to this conflict.

Most large TNDs have been built under zoning codes' planned unit development (PUD) provisions. ${ }^{107}$ Under PUD regulations, developers may mix otherwise quarantined land uses (such as apartments and shops) on one parcel of land, subject to governmental approval. ${ }^{108}$ PUD regulations, unlike Euclidean zoning, are not self-executing. ${ }^{109}$ To build a PUD, a developer must negotiate its own individual set of regulations with a local government, while Euclidean zoning allows a developer to obtain automatic approval of any structure that meets existing zoning rules (e.g., a single-family house in a single-family zone). ${ }^{110} \mathrm{So}$, if a municipality is unwilling to vary from conventional zoning standards, a New Urbanist developer will have to compromise or abandon its plans. ${ }^{111}$ Thus, PUDs are hardly the ideal tool for New Urbanist developers.

Even if a PUD process ultimately leads to a favorable outcome, the time wasted in developer/government negotiations may deter developers from building PUD New Urbanist projects. ${ }^{112}$ A developer's largest cost is the expense of holding land before development because until a building permit is issued, the developer is spending money on land without obtaining revenue from buyers or renters-obviously an unprofitable result. ${ }^{113}$ If a developer has to spend months in PUD-related negotiations to build a TND, but

ing finance, architecture, and sociology.").

104. See Jeremy R. Meredith, Note, Sprawl and the New Urbanist Solution, 89 VA. L. REV. 447, 492 (2003) ("A residence in [New Urbanist] communities comes not only at a high absolute price, but also at a premium over similar properties in the market area. One study found that New Urbanist homes cost eleven percent more than their market equivalents.") (footnotes omitted).

105. See Frug, supra note 1, at 1093 ("[V]irtually everything [New Urbanists] want to do is now illegal."); see also infra Part III.B (describing provisions in existing land use codes that conflict with New Urbanist goals as well as SmartCode's proposed reforms).

106. See supra notes $98-99$ and accompanying text.

107. See Joel Russell, Putting New Urbanism to Work in Your Community, in CoDIFYING NEW URBANISM, supra note 6, at 25, 30 (noting the "PUD process has typically been used as the vehicle for [large New Urbanist] projects").

108. See Lamer, supra note 7, at 402; Ohm \& Sitkowski, supra note 10 , at 786.

109. Ohm \& Sitkowski, supra note 10 , at 785-86.

110. See id. (explaining that while a developer operating under Euclidean zoning "need only obtain a building permit from the building inspector if he complied with all the standards," PUD regulations require that "standards are negotiated and agreed upon by a developer and a local community").

111. Id. at 786

112. See Lamer, supra note 7 , at 402 .

113. Id. 
can obtain a quick permit under Euclidean zoning to build a conventional single-use subdivision, it will generally prefer the latter option. ${ }^{114}$

Because the PUD process has not always yielded satisfactory results, New Urbanists have proposed a variety of alternatives to PUD zoning. One alternative is for a city to tweak its zoning code to allow more New Urbanist development. For example, Milwaukee's zoning code ${ }^{115}$ continues to divide the city into commercial and residential districts ${ }^{116}$ but has created a "mixed-use" district that includes both residential and office uses, ${ }^{117}$ allows some homes to be built on small lots, ${ }^{118}$ and has less restrictive parking regulations than other cities. ${ }^{119}$ But even so, Milwaukee's code is still a traditional Euclidean zoning code-one that limits density ${ }^{120}$ and often segregates land uses. ${ }^{121}$

A second alternative is New Urbanist zoning codes that encourage pedestrian-friendly, mixed-use design ${ }^{122}$ (sometimes referred to as "formbased codes" because they regulate building form more intensively than the activities going on inside buildings). ${ }^{123}$ These codes have taken a variety of forms.

A common form of New Urbanist zoning is the "TND District": ${ }^{124}$ that is, a provision within a zoning code creating a TND zone, just as the code creates residential and commercial zones. ${ }^{125}$ But if the TND zone or zones encompass a small part of a city or region, the TND District approach merely creates New Urbanist islands in a sea of sprawl.

DPZ has sought to remedy this problem by drafting a comprehensive New Urbanist code: the SmartCode. ${ }^{126}$ The SmartCode divides cities and/or

114. Id

115. See MILWAUKEE, WI., CODE ch. 295 (2004), available at http://www.city.milwaukee.gov /display/router.asp?docid=1179 [hereinafter MILWAUKEE CODE]; Russell, supra note 107, at 33 (listing Milwaukee as one of several cities that has adopted "comprehensive" zoning revisions to facilitate TNDs).

116. MilwaUkEe CODE, supra note 115, ch. 295-500 (for residential districts); id. ch. 295-600 (for commercial districts).

117. Id. ch. 295-501(4).

118. Id. tbl.295-505-2 (explaining that single-family house lots can be as small as 3,600 feet in some zones); $c f$. infra notes 178-191 and accompanying text (describing stricter regulations in other cities).

119. MILWAUKEE CODE, supra note 115, ch. 295-403(2) (requiring only two parking spaces for every three units in most multifamily zones); cf. infra notes 219-227 and accompanying text (describing stricter regulations in other cities).

120. See MILWAUKEE CODE, supra note 115, tbl.295-505-2 (listing minimum lot sizes for singlefamily homes and for multifamily dwellings as well).

121. See id. ch. 295-501, tbl.295-503-1 (listing various types of residential zones and showing that multifamily dwellings, offices, and retail shops are not allowed in most single-family residential zones).

122. See Ohm \& Sitkowski, supra note 10, at 786-87.

123. Id. at 787 (using term to describe New Urbanist codes generally); $c f$. Russell, supra note 107, at 36 (noting that form-based codes make "building type, street type, or a combination of the two the primary regulatory elements").

124. Russell, supra note 107 , at 30 (explaining that most TND codes require "rezoning to TND"that is, that land be included in "TND districts").

125. Id. at 30-31 (noting that TND zone is generally an optional floating zone-"[a] zoning district included in the text of the zoning ordinance, but not mapped in any specific locations until applications for development meeting the districts' standards are approved").

126. See Chael, supra note 29. 
regions into a "Transect" - a continuum of habitats ranging from most rural to most urban and the six zones that embody this diversity of habitats. ${ }^{127}$ Thus, the SmartCode could be used as a region-wide code rather than as a small part of a conventional code. ${ }^{128}$ Zones T1 and T2 are rural, ${ }^{129} \mathrm{~T} 3$ is suburban, ${ }^{130}$ and zones T4, T5, and T6 are urban. ${ }^{131}$ Within the region's "urban area," T4 is the least dense (consisting primarily of single-family houses and row houses), ${ }^{132}$ T5 is somewhat more compact (allowing buildings with up to five stories), ${ }^{133}$ and $\mathrm{T} 6$ is the functional equivalent of a downtown - the site of the densest residential, business, cultural, and entertainment concentration within a region. ${ }^{134}$ The purpose of the Transect is to create " immersive environments' - places where [the] physical characteristics of buildings [and] landscape . . . combine to create a coherent sense of place," 135 so that "urban" building forms such as high-rises are in urban rather than rural areas. ${ }^{136}$

While ordinary zoning codes regulate a building's character (e.g., its height, building and lot size, and parking facilities) by its use, the SmartCode regulates a building's character by the urban intensity of its zone-it sets up one set of rules for buildings in each zone, regardless of whether the buildings are being used for residential or commercial purposes. ${ }^{137}$ Several cities have incorporated some or all of the SmartCode into their zoning ordinances, and dozens of others (including numerous communities devastated by Hurricane Katrina) are contemplating doing so. ${ }^{138}$

127. See Ohm \& Sitkowski, supra note 10, at 790 ("A transect is a geographic cross-section of a region that can be used to identify a continuum of habitats, ranging from rural to urban, that vary by their level and intensity of urban character. The continuum of the transect lends itself to the creation of different zoning categories, from rural preserve to urban core.") (footnote omitted); SMARTCODE, supra note 29, tbl.1 (listing Transect zones).

128. Cf. supra note 30 (noting that a municipality can also allow developers to choose between SmartCode and conventional code, thus turning a SmartCode-governed area into a TND District).

129. See SMARTCODE, supra note 29, at SC18, SC20. The difference between T1 and T2 is that T1 includes untended wilderness, id. at SC18 \& tbl.1, while T2 includes land that is rural but mostly cultivated, such as agricultural land, id. at tbl.1.

130. Id. at SC20.

131. Id. In addition, the SmartCode creates a "Special District" (SD) classification for areas that cannot easily fit in to any of the other zones, such as large parks and airports. Id. art. 7, at SC147 (defining term).

132. See Duany \& Talen, supra note 7 , at 1463.

133. Id. at 1464 .

134. Id.

135. See Russell, supra note 107 , at 36 .

136. See id.

137. See, e.g., SMARTCODE, supra note 29 , art. 5.3 (setting forth rules governing suburban T3 zone, generally without reference to how land will be used).

138. See Quincy C. Collins, Officials to Learn SmartCode, BILOXI SUN HERALD, Jan. 19, 2006, at A7, available at 2006 WLNR 1047094 (focusing on hurricane-devastated Mississippi cities that are considering adoption of SmartCode); Placemakers, Information Clearinghouse, http://placemakers.com /info/infoClear.html (last visited Nov. 11, 2006) (listing communities). In addition, a few small towns here and there have adopted New Urbanist codes that are not Transect-based. See Russell, supra note 107, at 33 ("A number of smaller communities around the country, such as Comelius, Davidson, and Huntersville, North Carolina, have developed complete new ordinances."). 


\section{COMPARING CODES}

The primary purpose of this Article is to compare the SmartCode to conventional pro-sprawl land use regulation: that is, to show how the SmartCode supports (and occasionally fails to support) more pedestrianfriendly communities and to analyze whether the SmartCode is more intrusive than conventional land use regulation. The discussion below addresses these questions.

\section{A. A Note on Methodology}

Obviously, it is impractical to compare every conventional zoning code to the SmartCode. So I have chosen two codes to represent conventional zoning: one for an exceptionally automobile-oriented core city and another for a fairly typical suburb. The core city is Huntsville, Alabama, a city with just over 160,000 residents. ${ }^{139}$ Only $0.49 \%$ of Huntsville residents use public transit to get to work, fewer than all but 10 of the 245 American cities with over 100,000 people. ${ }^{140}$ Most of the ten cities more automobiledependent than Huntsville are suburbs of larger cities rather than regional core cities. ${ }^{141}$ Thus, Huntsville's level of automobile dependence is almost unique.

The "typical" suburb discussed below is Sugar Land, Texas, a large, growing ${ }^{142}$ Houston suburb that has gained some notoriety as the residence of former House Majority Leader Tom DeLay. ${ }^{143}$ Sugar Land is slightly less

139. See Haya El Nasser \& Paul Overberg, Rejuvenated Cities Capitalize on Location, USA TODAY, June 24, 2004, at 3A, available at 2004 WLNR 6661359 (noting that Huntsville had 164,237 people in 2003).

140. See The Carfree Census Database, Bikes at Work Inc., http://www.bikesatwork.com/carfree carfree-census-database.html (last visited Nov. 11, 2006). This site has a search engine that allows one to rank cities by transit ridership and other commuting-related variables. See id.

141. See id. The cities in question are Arlington, Amarillo, Grand Prairie, and McAllen in Texas; Gilbert and Peoria in Arizona; Livonia and Sterling Heights in Michigan; Overland Park, Kansas; and Cape Coral, Florida. Id. Arlington and Grand Prairie are suburbs of Dallas, while Gilbert and Peoria are suburbs of Phoenix. See Robert E. Lang \& Patrick A. Simmons, "Boomburbs": The Emergence of Large, Fast-Growing Suburban Cities, in REDEFINING URBAN AND SUBURBAN AMERICA 101, 106 (Bruce Katz \& Robert E. Lang eds., 2003). Overland Park is a suburb of Kansas City. See Nicole Stelle Garnett, The Public-Use Question as a Takings Problem, 71 GEO. WASH. L. REV. 934, 956-57 n.145 (2003). Livonia and Sterling Heights are suburbs of Detroit. See Lee Bollinger, Seven Myths About Affirmative Action in Universities, 38 WILLAMETTE L. REV. 535, 539 (2002); Craig Ruff, Country Folk

vs. City Folk: Election Results Lend Proof to Differences, DETROIT FreE PRESS, Dec. 16, 2004, at 23A. Cape Coral is a freestanding city but has reformed its zoning code to allow TND districts. See Osvaldo Padilla, Commercial Rules Set for Pine Island Road, FT. MYERS NEWS-PRESS, Feb. 10, 2004, at 3A (explaining the city has created "village districts" that will contain retail shops, offices, and housing). Two other cities with lower transit ridership are regional core cities; however, both are more compact than Huntsville. See U.S. Census Bureau, CountY AND CrTY Data BOOK: 2000, at tbl.C-1 (2000), available at http://www.census.gov/statab/ccdb/citl040a.txt (noting Huntsville has 909 people per square mile, while Amarillo and McAllen have 1,931 and 2,313 respectively); see also infra notes 192 194 and accompanying text (noting that lower density makes city less walkable).

142. See Carolyn Lochhead, GOP Leader's Texas Sweet Spot, S.F. ChrON., Jan. 5, 2003, at A1 (stating that Sugar Land grew from 24,000 people in 1990 to 63,000 in 2000).

143. Id. (describing Sugar Land in detail and calling Sugar Land "quintessential new suburbia"). 
auto-dependent than Huntsville; $1.5 \%$ of Sugar Land residents commute using public transit ${ }^{144}$ - a number that is only slightly below average for communities the size of Sugar Land. ${ }^{145}$

\section{B. Sprawl Zoning vs. New Urbanist Zoning: The Nuts and Bolts}

Conventional zoning, as exemplified by the Huntsville and Sugar Land municipal codes, favors automobile-dependent development by (1) discouraging mixed-use development, (2) mandating low density, (3) requiring landowners to place parking lots and landscaping in front of buildings, and (4) mandating anti-pedestrian street design. The discussion below will describe these sprawl-generating regulations and will then show how the SmartCode's provisions differ from those regulations.

\section{Mixed Use or Single-Use Zoning?}

\section{a) Single-Use Zoning and Its Fruits}

The Huntsville zoning code divides the city into over thirty districts, ${ }^{146}$ including seven types of residential districts, ${ }^{147}$ six business districts, ${ }^{148}$ and numerous special districts. ${ }^{149}$ Four of the residential districts (Districts 1, 1A, 1-B, and 1-C) are devoted primarily to single-family homes and related uses. ${ }^{150}$ Multifamily housing is not allowed in any of these districts nor are shops or offices. ${ }^{151}$ The city has also created two districts in which both single-family and multifamily dwellings are allowed. ${ }^{152}$ However, offices and shops are not allowed in the multifamily districts. ${ }^{153}$ Similarly, all of the city's six major commercial zoning districts ${ }^{154}$ exclude single-family dwellings, ${ }^{155}$ and two exclude multifamily buildings as well ${ }^{156}$ (as does the city's

144. The Carfree Census Database, supra note 140

145. Id. Of 419 American communities with between 50,000 and 100,000 people, Sugar Land ranks number 255 in its transit usage share. Id.

146. Huntsville, AlA., CODE OF ORdinANCES, app. A, art. 2.1, available at http:/www.municode .com/Resources/gateway.asp?pid=12962\&sid=1 [hereinafter HUNTSVILLE CODE]. Unless otherwise noted, all citations to the Huntsville Code are to Appendix A.

147. Id. at ch. I.

148. Id. at ch. II.

149. Id. at chs. III-VIII.

150. Id. art. 10.1 (in Residence District 1, permissible uses are limited to single-family dwellings and accessory structures, agricultural uses, churches and similar places of worship, and government-owned buildings); id. art. 11.1 (same uses allowed in Residence District 1-A); id. art. 12.1 (same uses allowed in Residence District 1-B); id. art. 16.1 (same uses allowed in Residence District 1-C). The difference between these districts is density: some have higher minimum lot sizes than others. See infra notes 179 , 182 and accompanying text.

151. See supra note 150 (multifamily dwellings, shops, and offices not among listed uses).

152. See HUNTSVILLE CODE, supra note 146, arts. 14-15.

153. Id. arts. $13.1,14.1,15.1$ (excluding retail and offices from among permitted uses in multifamily districts)

154. Id. art. 21.

155. Id. art. 20.1 (single-family dwellings not on list of permitted uses in District C-1); id. art. 21.1 (same true for District C-1A); id. art. 22.1 (same true for District C-2); id. art. 23.1 (same true for Dis- 
"residential office district"). ${ }^{157}$ In the other four business districts, the city allows only small multifamily buildings. ${ }^{158}$ Moreover, landowners are generally not allowed to build apartments over shops or offices. ${ }^{159}$

Sugar Land's zoning is even more rigorous. Sugar Land lists permitted and forbidden uses through a table known as a "Land Use Matrix." 160 The Matrix lists eight residential zones, including a townhouse zone and a multifamily zone. ${ }^{161}$ In all of these zones, most commercial uses are prohibited. For example, groceries, restaurants, drug stores, and office-oriented businesses are prohibited even in the city's multifamily zone. ${ }^{162}$ Similarly, single- and multifamily dwellings are not allowed in the city's office zones. ${ }^{163}$

In sum, the Sugar Land and Huntsville codes consistently prohibit even multifamily dwellings from being near offices or shops, thus creating cities in which "[v]ery few people . . . can simply walk to the local grocer . . . . Even if you are going to purchase a single item and the store is very close by, it is normally a car trip away." 164

trict C-3); id. art. 24.1 (same true for District C-4); id. art. 25.1 (same true for District C-5).

156. Id. art. 21.1 (multifamily dwellings not on list of permitted uses in District C-1A); id. art. 25.1 (same true for District C-5).

157. Id. arts. 80, 80.1. The purpose of this district is to allow dwellings to be converted to small offices in order to create a "transitional zone between existing residential and [nearby] commercial." Id. art. 80.

158. See id. arts. 20.2.1, 20.2.2(5) (in District C-1, "[m]aximum number of stories is three and maximum height is 50 feet"); id. arts. 22.1, 22.2 (identical restrictions in District C-2); id. arts. 23.3.1, 15.2.3 (multifamily dwellings in District C-3 subject to limits in article 15, which limits multifamily dwellings to three stories and a height of forty-five feet). The city does allow ten-story buildings in one district. Id. art. 24.2.1(13) (allowing buildings as high as ten stories in District C-4). However, the city requires 2,000 square feet of space per unit in District $\mathrm{C}-4$, thus making large apartment buildings arguably uneconomical. Id. art. 24.2.1(3); see Bemard H. Siegan, Non-Zoning in Houston, 13 J.L. \& ECON. 71, 119 (1970) (noting that requirements similar to District C-4's 2000-square-foot requirement made townhouses more expensive in Houston).

159. HUNTSVILLE CODE, supra note 146, art. 73.6 ("No building or structure may be used for residential purposes when said building or structure's primary purpose is used for office or other nonresidential uses ...."). Two narrow exceptions exist to this rule. First, residential dwelling units in District C-1 may be "on the second and/or third floors above commercial or office uses" if they are over 800 square feet. Id. art. 20.1.1. Thus, only large apartments over small offices are allowed. Second, in District C-3, mixed use is allowed with special municipal permission. Id. art. 73.6. The city also allows PUDs. See id. ch. III. But as noted above, PUDs are not favored by developers because cities have ample discretion to deny PUD applications. See supra notes 107-113 and accompanying text; see also HUNTSVILLE CODE, supra note 146, art. 30.5 .6 (city action on PUD applications "shall be as for zoning amendments generally"); id. art. 90.1 (allowing zoning amendments but setting no limits on city's discretion to deny such amendments).

160. See SugAR LAND, TEX., LAND DEvelOPMENT CODE § 2-55 (2005), available at http://www. municode.com/resources/gateway.asp?pid=13286\&sid=43 [hereinafter SUGAR LAND CODE].

161. See id. $\$ 2-51$ (identifying and describing the zones).

162. Id. § 2-55 SIC Groups $35,54,58,59$.

163. Id. SIC Group 99. Like Huntsville, Sugar Land also has a mixed-use "planned development" (PD) zone. Id. $\S 2-172$. However, the city treats PD applications as applications to amend the zoning code, which means that the city has ample discretion to deny PD applications. See id. § 2-175(a) ("The creation of a planned development district is an amendment to the existing zoning district classification and will be considered by the Commission and City Council, after public notice and hearing, in the same manner as other changes in zoning district classification."); id. § 2-12 (discussing zoning amendments and setting no limits on city's ability to deny such amendments); see also supra notes 107-113 and accompanying text (noting difficulties of PUD-type development).

164. Tondro, supra note 5, at 517. Of course, single-use zoning is not the only factor that prevents housing from being within walking distance of shops. As will be explained below, regulations mandating 


\section{b) The SmartCode's Reforms}

As noted above, the SmartCode creates six major zones: rural T1 and T2, suburban T3, and urban T4, T5, and T6. ${ }^{165}$ In this respect, the SmartCode is far simpler than Huntsville's zoning code (which contains dozens of districts) ${ }^{166}$ or Sugar Land's code (which contains seventeen districts). ${ }^{167}$

Like the Sugar Land code, the SmartCode includes a zoning matrix. ${ }^{168}$ Like the Huntsville and Sugar Land codes, the SmartCode creates a zone dedicated primarily to single-family houses: the T3 zone. ${ }^{169}$ However, the SmartCode allows small-scale office and retail use in the T3 zone. In the T3 zone, the first story of one out of every 300 buildings may be used for neighborhood stores and small restaurants. ${ }^{170}$ The SmartCode generally prohibits office development in the T3 zone ${ }^{171}$ but does allow "Live-Work Unit[s]"172 — dwelling units with a commercial component on the first floor. ${ }^{173}$ Moreover, the SmartCode allows extensive mixing of uses in the T4, T5, and T6 zones-in all three zones, housing, retail, and office space may coexist. ${ }^{174}$

Thus, the SmartCode's treatment of land use is more permissive than the Huntsville and Sugar Land codes. The SmartCode preserves singlefamily zoning districts but allows small-scale retail in the T3 zone so that even homeowners can walk to small stores and restaurants. ${ }^{175}$ And while the Huntsville and Sugar Land codes often ban offices and shops near apartments, ${ }^{176}$ the SmartCode consistently allows developers to mix shops and offices with multifamily housing so people can do errands on foot or walk to work. ${ }^{177}$

\footnotetext{
low density are also at fault. See infra notes 192-197 and accompanying text (describing impact of minimum lot size requirements).

165. See supra notes 129-134 and accompanying text.

166. See HUNTSVILLE CODE, supra note 146, chs. II-VI.

167. See SUGAR LAND CODE, supra note 160, § 2-51.

168. See SMARTCODE, supra note 29, at SC123 tbl.10.

169. See id. (explaining that multifamily dwellings are generally not allowed in the T3 zone nor is most large-scale office use or retail).

170. Id. at SC125 tbl.11 (noting that in $\mathrm{T} 3$ zone, retail use is limited "to one block corner location ... for each 300 dwelling units" and must seat "no more than 20 ").

171. See id. at SC123 tbl.10 (stating that office buildings are not allowed in T3 zone).

172. Id.

173. See id. art. 7, at SC141 (defining live-work units as dwelling units containing commercial components); id. at $\mathrm{SCl} 25$ tbl.11 (in T3 zone, offices are limited to first story of building).

174. Id. at $\mathrm{SC} 123$ tbl.10.

175. See supra notes $169-174$ and accompanying text.

176. See supra notes 153,159 and accompanying text.

177. See supra notes 170-174 and accompanying text.
} 


\section{Density and Zoning}

\section{a) The War on Density}

Euclidean zoning has generally sought to reduce density, ${ }^{178}$ and the zoning codes of Huntsville and Sugar Land are no exception. In Huntsville, single-family homes must (depending on the zone they are in) consume a minimum of 6,000 to 15,000 feet. ${ }^{179}$ Thus, the Huntsville city code effectively allows only about three to seven houses per acre in residential zones. ${ }^{180}$ In one of Sugar Land's residential zones, the minimum lot area is one and a half acres. ${ }^{181}$ In Sugar Land's other zones, homes must consume between 5,000 and 9,500 square feet of land ${ }^{182}$ (or about five to nine houses per acre). ${ }^{183}$ Sugar Land also prohibits homeowners from renting out rooms anywhere in the city ${ }^{184}$-so if a single person owns a house, that house is effectively limited to one occupant.

In both cities, multifamily housing is also subject to strict anti-density regulation. In Huntsville, multifamily dwellings generally must consume between 2,000 and 3,000 square feet per dwelling unit ${ }^{185}$ (or fourteen to twenty-two units per acre). ${ }^{186}$ Sugar Land similarly requires 2,178 square feet per dwelling unit in multifamily housing, ${ }^{187}$ thus limiting apartment and condominium density to twenty units per acre ${ }^{188}$-about one-fifth the den-

178. See Briffault, supra note 1 , at 253 .

179. See HUNTSVILLE CODE, supra note 146, art. 10.2.1 (minimum lot size in Residence 1 District is 15,000 square feet); id. art. 11.2.1 (minimum lot size in Residence 1-A District is 12,000 square feet); id. art. 12.2.1 (minimum lot size in Residence 1-B District is 7,500 square feet); id. art. 13.2.1(1) (minimum lot size in Residence 2 District is 6,000 square feet); $i d$. art. 14.2.1 (same rule for Residence 2-A District); id. art. 15.2.1 (same rule for Residence 2-B District). The Huntsville code does allow 5,500 square foot houses in older neighborhoods; however, the zoning classification governing the city's historic district may not be applied to new subdivisions. Id. arts. 16, 16.2.

180. I calculate as follows: An acre contains 43,560 square feet. Arthur Allen Leff, The Leff Dictionary of Law: A Fragment, 94 YALE L.J. 1855, 1905 (1985). Because 43,560 divided by 15,000 (the minimum number of square feet per house in Huntsville's Residence 1 District) is just under three, and 43,560 divided by 6,000 (the minimum lot size in Huntsville's Residence 2-A and 2-B Districts) is just over seven, the minimum lot size in Huntsville's single-family zones is about three to seven houses per acre. See also supra note 179 (listing minimum lot sizes by square footage).

181. See SUGAR LAND CODE, supra note 160, § 2-65(a) (establishing the minimum lot size for the Residential Estate District).

182. Id. $\S 2-73$ (a) (in "R-lR" zone, minimum lot size is 9,500 feet); id. $\$ \S 2-83$ (a), 2-88(a) (in R-1, HR-1 zones, minimum lot size is 6,600 feet); $i d$. $\$ 2-93$ (a) (in R-1Z zone, minimum lot size is 5,000 square feet).

183. See supra note 180 (describing method of calculating units per acre from minimum square footage per unit).

184. See SUGAR LAND CODE, supra note $160, \S 2-4(\mathrm{~d})(3)$ (noting that an occupant of single-family dwelling "may not lease or rent any portion of the dwelling to another person").

185. HUNTSVILLE CODE, supra note 146, art. 14.2.3(1) (3,000 square feet per unit in District 2-A); id. art. 15.2.3(1) (2000 square feet per unit in District 2-B). The 2,000-foot minimum applies in the business districts that allow multifamily housing. See id. arts. 20.2.1, 22.2, 23.3.1, 24.2.1(3). Attached singlefamily residences are subject to similar rules. See id. art. 13.2.3 (single-family attached residence must sit on at least 2,200 square feet of land).

186. See supra note 180 (describing method of calculating units per acre from minimum square footage per unit).

187. SUGAR LAND CODE, supra note $160, \S 2-117$ (a).

188. See supra note 180 (describing method of calculating units per acre from minimum square 
sity of many cities' walkable, prosperous neighborhoods. ${ }^{189}$ Both cities essentially ban mid- and high-rise apartments in most parts of the city: Sugar Land prohibits multifamily housing with over two and a half stories, ${ }^{190}$ and Huntsville generally prohibits multifamily housing with over three stories. ${ }^{191}$

\section{b) War on Density or War on Walking?}

In Sugar Land and Huntsville, government-created low density effectively forces residents into their cars for two reasons. First, if each residence consumes large amounts of land, fewer residences can be placed within a short walk of shops, jobs, or each other. ${ }^{192}$ Thus, anti-density rules reduce the number of people who can walk to errands or jobs.

Second, in low-density areas, very few people will live within walking distance of a bus or train stop, which in turn means that very few people can conveniently use public transit. ${ }^{193}$ By contrast, more compact neighborhoods increase transportation choices because a higher number of households per acre means more potential riders within a short walking distance of a bus or train stop. Typically, a neighborhood must have at least seven to fifteen dwelling units per acre to support significant transit service. ${ }^{194}$ Even if every foot of land in Huntsville or Sugar Land was occupied by housing to the maximum extent allowed by local zoning, the most compact single-family neighborhoods in Huntsville and Sugar Land (where regulations allow only seven to nine units per acre) would be at the low end of this range, ${ }^{195}$ and other neighborhoods would be far below this "transit minimum." 196 In fact, Huntsville and Sugar Land are even less dense than their regulations appear to contemplate because some land in both cities is used for nonresidential

footage per unit).

189. See JANE JACOBS, THE DEATH AND LIFE OF GREAT AMERICAN CITIES 211 (1961) (asserting that prosperous urban neighborhoods typically have at least 100 dwellings per acre).

190. See SUGAR LAND CODE, supra note 160 , \$ 2-117(c).

191. See supra note 158 (city mandates three-story limit in every zone but District 4 , and minimum lot size requirement limits high-rise construction in that zone).

192. Cf. Duany \& Talen, supra note 7, at 1447 (noting that in neighborhoods organized around pedestrian needs, "structures that meet the essential daily needs of residents, such as parks, schools, and stores," would be "within a quarter mile radius" of housing).

193. See Freilich, supra note 7, at 552 ("[ []n order to effectively encourage transit utilization, a development must be located so that residents are not required to walk a distance of greater than a quarter mile to a transit station."); id. at $552 \mathrm{n} .18$ (explaining that in low-density areas, transit use is rare "because commuters are required to travel too far to transit stations").

194. Id. (typically, seven to fifteen dwelling units per acre is the minimum required for viable transit service).

195. See supra note 179 (most compact single-family neighborhood in Huntsville has 5,500 square foot minimum lot size, or 7.92 units per acre); supra note 182 (most compact single-family neighborhood in Sugar Land has 5,000 square foot minimum, or 8.7 units per acre); supra note 180 (explaining method of calculating number of dwelling units per acre).

196. See supra note 181 and accompanying text (minimum lot size area in most sprawling Sugar Land zone is one and a half acres); supra notes 179-180 (minimum lot size in most thinly populated Huntsville zone is 15,000 square feet, or less than three houses per acre). 
purposes such as streets and commerce. ${ }^{197}$ So even if these cities had significant transit service, ${ }^{198}$ transit ridership would be quite low.

\section{c) The SmartCode and Density}

The SmartCode's density regulations are not quite comparable to those of Euclidean zoning codes. Rather than regulating the size of individual building lots, the SmartCode legislates overall densities for a zone as a whole. For example, T3 zones may have up to two dwelling units per acre (or 1,280 units per square mile), T4 zones four units per acre (or 2,560 per square mile), T5 zones six per acre (or 3,840 per square mile), and T6 zones twelve per acre $\left(7,680\right.$ per square mile). ${ }^{199}$

At first glance, these densities appear to be lower than those allowed in Huntsville and Sugar Land (three to nine units per acre in single-family zones, and fourteen to twenty-two units per acre in multifamily zones). ${ }^{200}$ However, the SmartCode's density criteria are not directly comparable to those of the Sugar Land and Huntsville zoning codes, because rather than setting forth minimum lot sizes for individual houses or apartment buildings, ${ }^{201}$ the SmartCode regulates gross density ${ }^{202}$ - density per acre for all land in a zone (including public infrastructure such as streets, as well as land used for nonresidential purposes). ${ }^{203}$ Because gross density figures include nonresidential land, a neighborhood's gross density is lower than the density for a subdivision or group of houses in the neighborhood. For example, the Back Bay of Boston has thirty units per acre gross density but

197. In fact, Huntsville has 423 dwelling units per square mile (or only 0.7 per acre) and Sugar Land has 875.6 (or only 1.3 per acre). See U.S. CENSUS BUREAU, UNITED STATES CENSUS 2000, available at http://www.census.gov/census2000/states (last visited Nov. 13, 2006) [hereinafter CENSUS INDEX] (to find statistics for individual cities, go to state's link on index, then click "State by Place" listing to find statistics for individual cities); supra note 180 (explaining method of calculating dwelling units per acre).

198. Which they do not. In Huntsville, bus service ends at 6 p.m. See City of Huntsville, Alabama, Public Transportation Division, http://www.ci.huntsville.al.us/PublicTran/public_trans.php (last visited Nov. 13, 2006). There is apparently no bus service in Sugar Land itself, though the fact that $1.5 \%$ of Sugar Land residents use public transit as part of their daily commute indicates that some Sugar Land residents may drive to nearby Houston and take buses there. See John B. Judis, Home Invasion-DeLay of the Land, NEw REPUBLIC, May 16, 2005, at 18 ("[Sugar Land] has no public transportation . . .."); see also Metropolitan Transit Authority of Harris County, Texas, Park \& Ride Locations, http://ridemetro.org/Schedules_and_Maps/park_and_ride_locations.asp (last visited Nov. 13, 2006) (showing that Houston bus system has numerous "Park and Ride" lots, some of which extend outside regular service area for bus system).

199. See SMARTCODE, supra note 29, at SC129 tbl.14; Leff, supra note 180, at 1905 (640 acres constitute a square mile); $c f$. SMARTCODE, supra note 29, at SC20, SC22 (describing density formulae for nonresidential land uses).

200. See supra notes 180-183, 186-188, and accompanying text.

201. See supra notes 179, 182, 186-187, and accompanying text (describing how Huntsville and Sugar Land codes regulate minimum lot size).

202. See SMARTCODE, supra note 29, at SC129 tbl.14.

203. See Vermont Forum on Sprawl, Resources for Density, http://www.vtsprawl.org/Resources/ density/density_main.htm (last visited Nov. 13, 2006) (explaining that "[g]ross density includes the infrastructure, like parks, streets, etc." in the acreage measured). 
seventy units per acre in its most compact residential sector. ${ }^{204}$ Thus, an area with the two to twelve units per acre gross density allowed in the SmartCode's non-rural zones may have residential neighborhoods that are at least twice as compact as that quota suggests and thus more compact than the neighborhoods contemplated by the Huntsville and Sugar Land codes. ${ }^{205}$

Moreover, the SmartCode creates additional flexibility through its "Transfer of Development Rights" (TDR) provisions. TDRs work as follows: a landowner who owns both rural land and more urban land may forego development rights in one parcel in exchange for the right to build at higher density than would otherwise be authorized in another (usually more urban) ${ }^{206}$ parcel. $^{207}$ The SmartCode provides that areas affected by TDRs may be built up at three times the usual density in the $\mathrm{T} 3$ and $\mathrm{T} 4$ zones (six units per gross acre in the T3 zone, twelve per gross acre in the T4 zone), four times the usual density (twenty-four units per gross acre) in the T5 zone, and eight times the usual density (ninety-six units per gross acre) in the T6 zone. 208

\section{Should Big Brother Mandate Strip Malls?}

\section{a) Conventional Zoning}

Both Huntsville and Sugar Land require that all commercial buildings be set back far from streets. In Huntsville, all buildings along major streets

204. See Lincoln Institute of Land Policy, Visualizing Density, http://www.lincolninst.edu /subcenters/visualizing_density/tour/t4.aspx (requires free registration to access website) (last visited Nov. 13, 2005).

205. I suspect that the single-family zones of those cities are roughly comparable to the $\mathrm{T} 3$ zone, and the apartment zones are roughly comparable to the T5 zone. Here's why: in the Back Bay neighborhood discussed above, residential neighborhood density is about $43 \%(30 / 70)$ of gross density. As noted above, minimum lot size regulations allow three to nine units per acre in Huntsville and Sugar Land. See supra notes 180,183 , and accompanying text. If the same $43 \%$ ratio applies in those cities, gross density in their single-family areas is about 1.3 to 3.9 (43\% of 3 and 9 respectively) units per acre, roughly comparable to the SmartCode's two units per acre requirement. Similarly, $43 \%$ of fourteen to twentytwo units per acre (the range of density quotas for multifamily dwellings in both Sugar Land and Huntsville) is about 6-9.5 units, roughly comparable to the SmartCode's T5 density quota. See supra notes 185-188 and accompanying text (describing Huntsville and Sugar Land regulations in more detail); SMARTCODE, supra note 29, at SC129 tbl.14 (listing density quotas).

206. See SMARTCODE, supra note 29, art. 3.4.3, at SC21 (stating overall densities "may be increased by the purchase of Development Rights"); id. art. 7, at SC149 ("[TDRs are] a method of relocating existing zoning rights from areas to be preserved as open space to areas to be more densely urbanized."). 207. See Dwight H. Merriam, Reengineering Regulation to Avoid Takings, 33 URB. LAW. 1, 24 (2001) ("TDR enables density to be transferred from one site to another parcel . . . The parcel that 'sends' development rights, such as one with a historic landmark on it, is highly restricted. The [first parcel's] density ... . is transferred to a 'receiving' parcel ... [ [which] is developed at a somewhat higher density than usually permitted.”); $c f$. Penn Cent. Transp. Co. v. City of N.Y., 438 U.S. 104 (1978) (upholding constitutionality of historic preservation regulations that gave landowners TDRs to be used on non-historic parcels of land).

208. See SMARTCODE, supra note 29, at SC129 tbl.14. In addition, the SmartCode's annotations note that the SmartCode should be customized to regional character. Id. at SC128 (explaining that SmartCode's statistics can be altered through "local calibration"). Thus, the drafters of the SmartCode would presumably endorse higher densities in already-compact cities than those set forth in the SmartCode. 
must be at least fifty feet from the street. ${ }^{209}$ On other streets, apartment buildings must be twenty to thirty feet from the street. ${ }^{210}$ Business structures on minor streets are subject to varying degrees of regulation, depending on their location: one zone has 100 -foot setbacks for all commercial buildings, ${ }^{211}$ another has no setbacks at all, ${ }^{212}$ and others have setbacks in the thirty to fifty foot range. ${ }^{213}$

Similarly, Sugar Land requires twenty-five-foot setbacks for apartment buildings, ${ }^{214}$ forty-foot setbacks for businesses on arterial streets, ${ }^{215}$ and twenty-five-foot setbacks for businesses on other streets. ${ }^{216}$ In addition, businesses with parking lots in front of buildings must place an additional fifteen feet of landscaping between the parking lot and the street. ${ }^{217}$

Both Huntsville and Sugar Land encourage landowners to favor parking over other possible uses in those cities' "setback areas" by requiring landlords and developers to provide large amounts of (presumably free) ${ }^{218}$ offstreet parking to tenants. Even though $13 \%$ of Huntsville renters have no car in their householdd ${ }^{219}$ Huntsville requires landowners to provide 1.25 spaces per housing unit ${ }^{220}$-a rule that means that single-occupant units will have more "spaces" for cars than for people.

Huntsville's office landlords must provide one parking space per 400 feet of floor area ${ }^{221}$ (or 2.5 spaces per 1,000 square feet) and retail shops

209. HUNTSVILLE CODE, supra note 146, art. 73.15 ("A minimum setback of 50 feet . . shall be required along all major arterials ...."). A major arterial is a street "designed to accommodate the highest traffic volumes." Id. art. 3.1 .

210. Id. arts. 73.13.4(1)(d), (2)(d) (in District 2-A, multifamily dwellings must be thirty feet from street; in other districts, multifamily dwellings must be twenty feet from street).

211. Id. art. 21.2.1 (requiring 100 foot setbacks in C-1A District).

212. Id. art. 23.3 (no requirements for $\mathrm{C}-3$ District).

213. Id. art. 20.2.2(1) (thirty-foot minimum setback in C-1 District); id. art. 22.2 (same rules apply to C-2 District); id. art. 24.2.4(1) (fifty-foot minimum setback in C-4 District); id. art. 25.5.2 (same minimum applies to structures in C-5 District facing a public street).

214. See SUGAR LAND CODE, supra note $160, \S 2-117(\mathrm{~d})(1)$

215. Id. \$§ 2-125(b)(1) (requiring forty-foot setbacks for structures in "Business Office District" on arterial streets), 2-133(b)(1) (same nule governs business district B-1), 2-143(b)(1) (same rule governs business district B-2); see also FHWA GUDELINES, supra note 85 and accompanying text (defining "arterial" streets).

216. SUGAR LAND CODE, supra note 160, § 2-125(b)(1) (requiring 25-foot setbacks for structures in "Business Office District" not on arterial streets); id. § 2-133(b)(1) (same rule governs business district B-1); id. § 2-143(b)(1) (same rule governs business district B-2).

217. Id. §3-6.

218. Ninety-nine percent of parking in the United States is free to drivers. See DONALD C. SHOUP, THE HIGH COST OF FREE PARKING 1 (2005). Because Huntsville and Sugar Land are both more automobile-dependent than the United States as a whole, it seems likely that the same is true for both cities. See M. Gregg Bloche, Obesity and the Struggle Within Ourselves, 93 GEO. L.J. 1335, 1343 n.48 (2005) (noting that nationally, $87 \%$ of Americans drive to work, and $5 \%$ of Americans commute to work via public transit); The Carfree Census Database, supra note 140 (showing that, by contrast, in both Sugar Land and Huntsville, over $97 \%$ of workers commute by car and fewer than $2 \%$ use public transit).

219. See Huntsville, AL, Houses and Residents, http://www.city-data.com/housing/houses-Huntsville -Alabama.html (last visited Nov. 13, 2006) (stating 3427 of city's 25,584 renter-occupied housing units have no car).

220. HUNTSVILLE CODE, supra note 146, art. 70.1.3. And in one district, District 2-A, landlords must provide 1.5 spaces per housing unit. $I d$.

221. Id. art. 70.3 . 
must provide one parking space for each 300 feet of floor area ${ }^{222}$ (or 3.3 spaces per 1,000 feet). Huntsville's code also imposes use-specific requirements for over a dozen other activities. ${ }^{223}$

Sugar Land requires landlords to provide more housing for cars than for people, dictating construction of 1.5 parking spaces for each one bedroom apartment. ${ }^{224}$ Office buildings must provide one parking space per 250 square feet (or 4 per 1,000 feet), and most other commercial uses must provide one per 200 square feet (or 5 per 1,000 feet) ${ }^{225}$ Four parking spaces typically take up 1,200 square feet (including area for ramps and access lanes). ${ }^{226}$ Thus, Sugar Land effectively requires commercial landlords to provide more space for parking than for actual offices $(1,200$ feet of parking space for every 1,000 feet of office space). ${ }^{227}$

Both Huntsville and Sugar Land favor off-street parking over on-street parking. Huntsville actually prohibits on-street parking within its borders. ${ }^{228}$ Sugar Land does not directly prohibit on-street parking; however, Sugar Land's zoning code provides that only off-street parking may satisfy the requirements discussed above, ${ }^{229}$ and Sugar Land's street design standards prohibit on-street parking on any street with four or more lanes. ${ }^{230}$

\section{b) The Side Effects of Strip Malls}

As a result of municipal setback and minimum parking requirements, landowners typically surround offices, shops, and apartments with parking lots, thus creating a "strip mall" effect. ${ }^{231}$

222. Id.

223. Id.

224. SUGAR LAND CODE, supra note 160, § 2-215(a). Sugar Land's requirement of two parking spaces for two bedroom apartments is somewhat more reasonable. Id.

225. Id. As in Huntsville, numerous uses are subject to use-specific requirements, including car washes, retirement housing, day care facilities, community centers, hotels and motels, convalescent homes, hospitals, country clubs, various types of schools, funeral homes, churches and other assembly halls, lodges, industrial buildings, equipment sales buildings, banks, eating and drinking establishments, and showrooms. Id.

226. See SHOUP, supra note 218 , at 31 .

227. This statistic may actually underestimate the degree of parking regulation in Sugar Land: the city also requires parking lots for multifamily buildings to be more than twenty-five feet from the street, thus effectively increasing the city's setback requirement by the size of the parking lot. SUGAR LAND CODE, supra note 160, § 2-211(a). "In [n]onresidential [d]istricts, [p]arking [1]ots must maintain the minimum [s]etbacks specified for the particular district." Id. \$ 2-211(c).

228. See HUNTSVILLE CODE, supra note 146, art. 80.5 ("All parking shall be off-street .....").

229. See SUGAR LAND CODE, supra note $160, \S 2-215$ (describing list of parking requirements as "Off-Street Parking Schedule").

230. City of Sugar Land, Pavement Geometric Design Standards, app. F-5, at 5, http://www.ci.sugarland.tx.us/community_dev/engineering/documents/pdf/appendix_f.pdf (last visited Nov. 13, 2006) [hereinafter Sugar Land Design].

231. See JAMES HOWARD KUNSTLER, HOME FROM NOWHERE 138 (1996) (setback laws generally "keep buildings far away from the street in order to create parking lots all around the building"); Michael Lewyn, How Overregulation Creates Sprawl (Even In A City Without Zoning), 50 WAYNE L. REV. 1171, 1183 n.82 (2004) (where buildings are set back from the street, "shopping centers and restaurants are designed with parking out front, creating a strip mall effect" (quoting Julie Mason, Urban Reviewal, HOUSTON CHRON., Aug. 18, 1997, at 1, available at 1997 WLNR 6626553) (internal quotation marks omitted)). Parking lots are generally in front of buildings for two reasons. First, if setback rules require 
Government-mandated strip malls create a sprawling, automobiledependent urban form in several ways. First, strip mall landscapes are visually unappealing for pedestrians. An Environmental Protection Agency report states that where buildings are set back behind yards of parking rather than being "flush with the sidewalk,",232 a pedestrian "has less to look at [and] feels more isolated."233 By contrast, "small setbacks and shopfront windows provide more interesting scenery for pedestrians, and create a feeling of connection between the buildings and the public spaces bordering them.",234

Second, parking lots in front of buildings lengthen pedestrians' commutes by increasing the distance between streets and destinations such as offices and shops. ${ }^{235}$ Where parking is in front of a shop, pedestrians cannot approach the shop without trudging through an uninviting parking lot and dodging cars on the way to their errand. ${ }^{236}$

Third, minimum parking requirements discourage walking and transit use by reducing the density of population and jobs because land devoted to parking cannot be used for apartments or commerce. ${ }^{237}$ For example, in 1961, Oakland began to require one parking space per dwelling unit for apartment buildings. ${ }^{238}$ Within just three years, the number of apartments per acre fell by $30 \% .{ }^{239}$ And by reducing residential density, minimum parking requirements reduce the number of people who can live within walking distance of shopping, jobs, or public transit. ${ }^{240}$

Finally, minimum parking requirements subsidize driving. While roads are at least partially paid for by user fees, ${ }^{241}$ parking is nearly always "free" to its users. ${ }^{242}$ But such "free" parking is in fact paid for by landowners, who build parking lots and in turn pass the costs of those parking lots to

landowners to place something in front of buildings, those landowners have a strong incentive to use the "setback space" for a parking lot that the landowner's tenants and customers can use (as opposed to landscaping that is merely decorative). Second, as long as the landowner has to install a parking lot, she might as well place the lot in front of her property where motorists can easily see it. See SHOuP, supra note 218, at 107 (parking in front of buildings is more convenient for motorists than rear parking).

232. EWING, supra note 80, at 10.

233. Id.; see also Sutherland, supra note 9 (explaining that setbacks cause streets to seem "vast" and "unfriendly looking").

234. Douglas G. French, Cities Without Soul: Standards for Architectural Controls with Growth Management Objectives, 71 U. DET. MERCY L. REV. 267, 280 (1994).

235. See Freilich, supra note 7, at 557 (explaining that "large expanses of asphalt devoted to parking often discourages pedestrian mobility" and make public transit inconvenient by impeding walking to and from transit stations); see also infra note 286 and accompanying text (noting that wide streets have similar effects by increasing distance between two sides of a street).

236. Freilich, supra note 7, at 557.

237. See supra notes 192-194 and accompanying text (noting that low-density areas tend to be highly automobile-dependent).

238. See SHOUP, supra note 218 , at 143.

239. Id. at 144 (describing the study and noting that the study was performed in 1964, just three years after the requirement was enacted into law).

240. See supra notes 192-194 and accompanying text.

241. See Salvatore Massa, Surface Freight Transportation: Accounting for Subsidies in a "Free Market," 4 N.Y.U. J. LEGIS. \& PUB. POL'Y 285, 318 (2001) (noting over half of state and federal highway spending is paid for by user fees).

242. See SHOUP, supra note 218 , at 1 ( $99 \%$ of American auto trips involve free parking). 
society as a whole in the form of higher rents, and by their business tenants, who in turn pass the costs on to society as a whole in the form of higher prices for goods and services. ${ }^{243}$ Thus, minimum parking requirements are essentially a sort of tax that redistributes money from society as a whole (including both nondrivers and all Americans in their roles as consumers and business owners) to drivers. ${ }^{244}$

Moreover, the impact of this "tax" is quite large. According to one 2002 study, the cost of an average parking space is about $\$ 127$ per month. ${ }^{245}$ Assuming that a commuter drives to work twenty-two days a month, that commuter receives a parking subsidy of $\$ 5.77$ per day to park free $(\$ 127 / 22$ days). ${ }^{246}$ Given that the same commuter spends far less than $\$ 5.77$ to drive to work, ${ }^{247}$ free parking is more valuable to drivers than free gasoline would be.

In sum, government-mandated free parking provides a huge subsidy to drivers-which means that government-mandated free parking increases driving, just as government-provided "free" pizza would increase the number of Americans eating pizza. ${ }^{248}$ And where driving is subsidized, the demand for public transit service is lower. This means that public transit agencies have less revenue, which means that those transit agencies will provide less service, ${ }^{249}$ thereby increasing automobile dependence still further.

As noted above, the Huntsville and Sugar Land codes disfavor on-street parking ${ }^{250}$ - a bias that makes those cities less comfortable for pedestrians in two ways. First, on-street parking protects pedestrians from auto traffic be-

243. Id. at 2 ("Initially the developer pays for the required parking, but soon the tenants do, and then their customers, and so on, until the cost of parking has diffused everywhere in the economy. When we shop in a store, eat in a restaurant, or see a movie, we pay for parking indirectly because its cost is included in the prices of merchandise, meals, and theater tickets.").

244. Id. ("We don't pay for parking in our role as motorists, but in all our other roles-as consumers, investors, workers, residents, and taxpayers-we pay....").

245. Id. at 185-91 (explaining logic behind estimate); id. at 192 (many commercial spaces cost even more, so $\$ 127$ per month may be a low estimate).

246. Id. at 212.

247. In 2001, the average American commuter had a twenty-six-mile round trip commute and a car using twenty miles per gallon, and thus used up 1.3 gallons of fuel per day. See id. at 213 (noting that these are average commute and mileage lengths in the United States). In February 2006, gas prices were about just over $\$ 2$ per gallon, so the hypothetical commuter cited above would pay just under $\$ 3$ per day for gasoline. See Louis Uchitelle \& Megan Thee, Poll: Gas Tax Increase OK If Its Results Are Measurable, PITTSBURGH POST-GAZETTE, Feb. 28, 2006 at A5, available at 2006 WLNR 3422288 (noting that nationwide average price of gasoline was $\$ 2.24$ per gallon at time of article).

248. See DUANY ET AL., supra note 8, at 94 ("Of course there's never enough parking! If you gave everyone free pizza, would there be enough pizza?" (internal quotation marks omitted)).

249. See Fitchik v. N.J. Transit Rail Operations, Inc., 873 F.2d 655, 665 (3d Cir. 1989) (Rosenn, J., dissenting) ("[I]ncreases in fares or reductions in the quality or availability of service have the tendency of reducing ridership, and the reduction in ridership in turn diminishes revenue."); Editorial, To Bus or Not To Bus, PROVIDENCE J. BULL., Nov. 18, 2004 at A8, available at 2004 WLNR 11550012 (noting that possible cuts in bus service will "cause ridership to fall, deficits to swell and the 'death spiral' to become ever more costly to stop"). And in fact, bus service between Sugar Land and Houston was eliminated due to low ridership. See Eric Hanson, Commuter Service Hits Dead End: Funds Expire for Commuter Bus Route to Houston's Galleria Area, HouSTON CHRON., July 31, 2003, at A29, available at 2003 WLNR 10899535 (bus from Sugar Land to Houston terminated due to "low ridership numbers"). 250. See supra notes 228-230 and accompanying text. 
cause parked cars create a barrier between walkers on sidewalks and drivers on streets. ${ }^{251}$ Second, on-street parking delivers drivers to spaces right in front of sidewalks, thus encouraging them to use those sidewalks on the way to their destinations, ${ }^{252}$ thus making streets feel less deserted and safer. By contrast, off-street parking encourages drivers to go straight from home to a parking lot.

\section{c) The SmartCode vs. the Strip Mall}

The SmartCode completely reverses the setback rules of conventional zoning while merely moderating the excesses of conventional parking regulation.

\section{i) The SmartCode and Setbacks}

As noted above, the SmartCode requires that most apartments, shops, and offices be in the T4, T5, and T6 zones. ${ }^{253}$ And in those zones, setback requirements are minimal. In the $\mathrm{T} 4$ zone, the minimum front setback is six feet. ${ }^{254}$ There are no minimum front setbacks in the T5 and T6 zones. ${ }^{255}$

In fact, the SmartCode imposes maximum setback rules for the most urban zones, ranging from twelve feet in the T5 and T6 zones to eighteen feet in the T4 zone. ${ }^{256}$ So in those zones, a landowner may not build a shopping center dozens of feet from the street. Thus, the SmartCode's setback rules are not significantly more libertarian than those of conventional zoning: both use setbacks to promote a vision of urban form.

\section{ii) The SmartCode and Parking Flexibility}

At first glance, the SmartCode's parking requirements seem similar to those of Sugar Land and Huntsville. The SmartCode requires landowners in the $\mathrm{T} 3$ and $\mathrm{T} 4$ zones to provide 3 parking spaces per 1,000 square feet for

251. See Frank Spielberg, The Traditional Neighborhood Development: How Will Traffic Engineers Respond?, ITE J., Sept. 1989, at 18, available at http:/www.ite.org/traffic/documents/JIA89A17.pdf. 252. See DUANY ET AL., supra note 8, at 71 ("[P]arallel parking supports pedestrian life by delivering people to the sidewalk [who] . . . often walk past shops or houses other than the one they are visiting.").

253. See supra notes 169-174 and accompanying text (T3 zone is dominated by single-family homes, while more urban zones are more mixed-use in nature). The SmartCode also requires a twenty-four-foot front setback in the T3 zone. See SMARTCODE, supra note 29, at SC129 tbl.14. But the T3 setback requirement does not affect pedestrians very much because the T3 zone is dominated by single-family houses rather than by relatively public spaces such as shops or offices. See supra notes 169-174 and accompanying text.

254. See SMARTCODE, supra note 29, at SC129 tbl.14. The purpose of this requirement is to encourage porches, outdoor seating for restaurants, and similar aesthetically desirable encroachments on streets. Id. at SC48.

255. Id. at $\mathrm{SC} 129$ tbl. 14 .

256. Id. 
office development, 4 per 1,000 square feet for retail development, ${ }^{257}$ and at least 1.5 parking spaces per residential unit. ${ }^{258}$

But the SmartCode softens its parking mandates in the following respects:

*The SmartCode's parking requirements for the T5 and T6 zones are more lenient than its requirements for other zones. In the T5 and T6 zones, the SmartCode requires landowners to provide 2 spaces per 1,000 square feet for offices ( $1 / 3$ fewer than in the T3 zone), 3 per 1,000 square feet for retail (1/4 fewer than in the $\mathrm{T} 3$ zone), and 1.5 per dwelling unit for residences (1/3 fewer than in the T4 zone and half as many as in the T3 zone). ${ }^{259}$

*The SmartCode counts on-street parking as part of the minimum required number of parking spaces, ${ }^{260}$ thus essentially exempting the smallest businesses from its requirements. ${ }^{261}$ By allowing on-street parking, the SmartCode not only reduces regulatory burdens upon businesses but increases street life (by encouraging drivers to use the sidewalks on the way to their destinations) and protects pedestrians by creating a buffer of parked cars between pedestrians on sidewalks and traffic on streets. ${ }^{262}$

*The SmartCode, through a complex formula, reduces parking requirements for landowners who are willing to share parking. ${ }^{263}$ For example, if an apartment building would ordinarily be required to provide ten parking spaces under the SmartCode and an office would ordinarily be required to provide twelve spaces, the two buildings would only be required to provide sixteen spaces (instead of the twenty-two they would ordinarily have to supply) if they agreed to share parking. ${ }^{264}$

In one respect, the SmartCode actually increases regulation in order to limit the anti-pedestrian results of parking regulations. Instead of encouraging landowners to place parking in front of buildings, the SmartCode requires parking lots to be surrounded by walls or by other buildings. ${ }^{265}$ In other words, the SmartCode places parking lots in the middle or rear of

257. Id. at $\mathrm{SC} 125$ tbl.12.

258. Id. In addition, the SmartCode requires two parking spaces per dwelling in the $\mathrm{T} 3$ zone (dominated by single-family dwellings), a requirement roughly identical to those of the Huntsville and Sugar Land codes. Id.; see also HUNTSVILLE CODE, supra note 146, art. 70.1.3 (two spaces per single-family dwelling unit in Districts 1 and 1-A, one per unit in other districts); SUGAR LAND CODE, supra note 160, $\$ 2-215$ (a) (single-family dwellings must have two parking spaces).

259. See SMARTCODE, supra note 29, at SC125 tbl.12.

260. See id. arts. 5.3.4(b), at SC41 (for T3 zone); 5.4.4(b), at SC51 (for T4 zone); 5.5.4(b), at SC59 (for T5 zone); and 5.6.4(b), at SC67 (for T6 zone).

261. Because if a business has two parking spaces at its door, but consumes only 500 square feet of space, the two parking spaces completely satisfy its minimum parking requirement of four spaces per 1,000 square feet.

262. See supra notes 251-252 and accompanying text (discussing advantages of on-street parking).

263. See SMARTCODE, supra note 29, at S125 tbl.12.

264. Id. art. 5.5.3.3, at SC56-SC58.

265. Id. arts. 5.3.4(e) (T3 zone), 5.4.4(e) (T4 zone), 5.5.4(e) (T5 zone), and 5.6.4(e) (T6 zone). Specifically, these provisions require parking lots to be surrounded either by a liner building (that is, "a building specifically designed to mask a parking lot") or a streetscreen (that is, "[a] freestanding wall ... often for the purpose of masking a parking lot"). Id. art. 7 (defining terms). 
buildings instead of in front, thus allowing pedestrians to enter buildings without having to go through a wasteland of parking. ${ }^{266}$ In sum, the SmartCode retains minimum parking requirements-but by reducing regulation in some respects while increasing regulation in other ways, the SmartCode makes those requirements less harmful to the urban fabric.

\section{Street Design: Streets for Cars or for Everyone?}

Ever since the 1930 s, local governments have tended to require longer and wider streets and have favored cul-de-sacs over grid streets. ${ }^{267}$ Cities typically regulate streets not just by building streets themselves but also through subdivision codes that tell developers how to build streets in new subdivisions. ${ }^{268}$

Highway planners generally divide streets into three major categories: arterial streets are those with the heaviest traffic, ${ }^{269}$ local streets are smaller, residential streets, ${ }^{270}$ and "collector" streets intersect with both arterial and local streets. ${ }^{271}$

\section{a) Fat Streets or Skinny?}

\section{i) Huntsville and Sugar Land: Big Fat Streets}

Although Huntsville has no minimum pavement width for collector and arterial streets, Huntsville's code mandates that individual lanes be twelve feet wide on nonresidential arterial and collector streets, ${ }^{272}$ far wider than many pre-World War II street lanes. ${ }^{273}$ New Huntsville arterial and collector streets typically have three to five lanes ${ }^{274}$ and thus have at least thirty-six to sixty feet of pavement. ${ }^{275}$ One Huntsville arterial has ten lanes and thus has over 100 feet of pavement. ${ }^{276}$

266. The SmartCode also notes that cities may enact maximum parking requirements, but does not specify what those requirements should be. Id. arts. 5.3.4(c) (T3 zone), 5.4.4(c) (T4 zone), 5.5.4(c) (T5 zone), and 5.6.4(c) (T6 zone).

267. See supra notes 75-77 and accompanying text (FHA favored cul-de-sacs); supra note 83 and accompanying text (local governments generally followed FHA standards).

268. See, e.g., HUNTSVILlE CODE, supra note 146, app. B, art. 1.4(2) (explaining that owners of land wishing to subdivide land for development must conform to minimum requirements set forth in subdivision regulations); SUGAR LAND CODE, supra note $160, \S 5.2$ (making same point).

269. See supra note 86.

270. See supra note 78 and accompanying text (local streets primarily residential and typically twenty-six feet wide); supra notes 87-88 and accompanying text (arterial streets much wider).

271. See supra note 86.

272. See HUNTSVILLE CODE, supra note 146, app. B, art. 4.5(5) tbl.2.

273. See DUANY ET AL., supra note 8, at 65 ("[T]ravel lanes on old streets are often only nine feet wide or less ....").

274. See Email from Dan Sanders, P.E., Traffic Engineer IV, to Michael Lewyn, Assistant Professor of Law, Florida Coastal School of Law (Mar. 10, 2006) (on file with author) [hereinafter Sanders Letter] ("We use 3- and 5- lane sections, to accommodate left turns.").

275. See supra note 272 and accompanying text (Huntsville subdivision regulations require twelvefoot lanes on most nonresidential streets).

276. See Email from Dan Sanders, P.E., Traffic Engineer IV, to Michael Lewyn, Assistant Professor 
Huntsville's regulation of local streets is more modest: Huntsville requires only that local streets have pavement (as opposed to sidewalks and landscaping) ${ }^{277}$ at least twenty-six feet wide ${ }^{278}$-narrower than Huntsville's other streets, but still wider than many pre-World War II streets. ${ }^{279}$

Sugar Land's rules are less flexible. Sugar Land regulates streets through a set of design standards which provide, inter alia, that Sugar Land's arterials must have forty-eight to ninety-six feet of pavement, ${ }^{280}$ and that collector streets must (if they have more than two lanes) have forty-four feet of pavement. ${ }^{281}$ Sugar Land's local streets are roughly the same size as Huntsville streets; Sugar Land's code requires that local streets have twenty-seven feet of pavement. ${ }^{282}$

\section{ii) Are the Streets Too Big?}

As noted above, local streets in Huntsville and Sugar Land are typically twenty-six to twenty-seven feet wide, and in Sugar Land, major streets must usually be over forty feet wide. ${ }^{283}$ By contrast, some cities have commercial streets as narrow as twenty-eight to thirty feet wide ${ }^{284}$ and residential streets as narrow as eighteen to twenty feet wide. ${ }^{285}$

The wide streets favored by conventional land use codes discourage walking in a variety of ways. First, a wide street lengthens pedestrian com-

of Law, Florida Coastal School of Law (Dec. 6, 2005) (on file with author). Although the Huntsville code does not explicitly require such wide streets, its right-of-way regulations indirectly encourage large amounts of pavement. The Huntsville code requires that "minor" collectors have sixty feet of right-ofway, major collectors eighty feet, and arterial streets 120 feet. See HUNTSVILLE CODE, supra note 146, app. B, art. 4.5(5) tbl.1. Right-of-way includes sidewalks and landscaping as well as pavement. Id. app. B, art 2.2; cf. Southworth \& Ben-Joseph, supra note 70, at 79 (showing diagram of street with sixty-foot right-of-way, including thirty-four feet of pavement, fourteen feet of landscaping, and twelve feet of sidewalks).

277. See HUNTSVILLE CODE, supra note 146, app. B, art. 4.6 (streets must generally have sidewalks as well as landscaping between sidewalks and streets).

278. Id. art. $4.5(5)$ tbl.3.

279. See Southworth \& Ben-Joseph, supra note 77 , at 19 fig. $8 \mathrm{~b}, 26$ fig.10b (showing examples of smaller pre-war streets).

280. See Sugar Land Design, supra note 230, app. F-5 (noting that all arterials must have twelvefoot-wide lanes; thus, eight-lane streets have ninety-six feet of pavement, six-lane streets seventy-two feet, and four-lane streets forty-eight feet). Land not used for parking may be used for landscaping and medians, id., as well as sidewalks. City of Sugar Land, Paving Design Requirements, div. 6.7, http://www.sugarlandtx.gov/community_dev/engineering/design_standards/division_six.asp (last visited Nov. 13, 2006) [hereinafter Sugar Land Paving Design] (regulating sidewalks).

281. Sugar Land Design, supra note 230, app. F-5 (four-lane collectors must have four eleven-foot lanes). However, two-lane collectors need only be thirty-six feet wide from curb to curb. $I d$.

282. Id.

283. See supra notes 280-281 and accompanying text (describing how arterial streets in Sugar Land must be at least forty-eight feet wide, and collectors must be at least forty-four feet wide under certain circumstances).

284. See Lewyn, supra note 231, at 1187; City of Boise, Planning and Development Services: Compact Infill Development Sites, http://www.cityofboise.org/pds/infill/index.aspx?id=8thStreet (last visited Nov. 13, 2006) (describing how one Boise street is only twenty-eight feet wide; city suggests that street's form "takes back the rights of pedestrians to use an area without abolishing auto use in the same venue").

285. See Lewyn, supra note 231 , at 1187 . 
mutes because a wide roadway takes longer to cross than a narrower street. $^{286}$

Second, wide streets may also be more dangerous for pedestrians because the more time a pedestrian spends crossing the street, the more time the pedestrian is exposed to traffic. ${ }^{287}$ Moreover, wide streets may also endanger pedestrians by encouraging motorists to drive faster. ${ }^{288}$ Fast traffic may increase the number of accidents because a motorist driving thirty miles per hour has a field of vision spanning about 150 degrees, while a motorist driving sixty miles per hour has a 50 -degree field of vision. ${ }^{289}$ Fast traffic also increases the severity of accidents: the probability of a pedestrian being killed by an automobile is only $3.5 \%$ where the auto is traveling fifteen miles per hour, increases to $37 \%$ if the auto is traveling thirty-one miles per hour, and increases to $83 \%$ if the auto is traveling forty-four miles per hour. $^{290}$

Third, wide streets take more space from landowners than do narrower streets-which means less compact development because wide streets take land that landowners could use to build housing. ${ }^{291}$ As noted above, lowerdensity areas tend to be unpleasant for pedestrians and transit users, because fewer places will be within walking distance of a particular spot than in more compact areas. ${ }^{292}$

Finally, wide streets will often deprive pedestrians of a feeling of enclosure-the feeling of being in a room instead of being in a desert. ${ }^{293}$ One New Urbanist commentator asserts that "the relationship of width to height cannot exceed a certain ratio .... If the distance from building front to building front [on the other side of a street] is more than six times the height of those building fronts, the feeling of enclosure is lost, and with it the sense of place." 294

In sum, wide streets are often ugly, inconvenient, and perhaps even dangerous for pedestrians, and they reduce the amount of land available to private landowners by shifting land from private ownership to public streets.

286. See Donavan v. Jones, 658 So. $2 d$ 755, 765 (La. Ct. App. 1995) (describing expert testimony that "a wider roadway takes longer to cross").

287. Id.

288. See Burrington, supra note 2, at 701 (explaining that larger roads are caused by government "solicitude toward fast traffic"); SMARTCODE, supra note 29, art. 3.6, at SC26 (pedestrians will not walk into "a street that they feel endangers them because the traffic is moving too fast").

289. See Burrington, supra note 2, at 704 n.50.

290. Id. at 704 .

291. See Michele Derus, Zoning Can Curb Lower-Cost Housing, MilwaukeE J. SenTINEL, Sept. 21, 1997, at 1, available at http://calbears.findarticles.com/p/articles/mi_qn4196/is_19970921/ai_n10359570 (each ten feet of required street width reduces housing supply by $3-4 \%$ ).

292. See supra notes $192-201$ and accompanying text.

293. See DUANY ET AL., supra note 8, at 78 ("If a street is to provide the sense of enclosure that pedestrians desire-if it is to feel like a room-it cannot be too wide.").

294. Id. 


\section{iii) SmartCode Flexibility}

The SmartCode regulates the width of streets and travel lanes through a table of street designs listing about two dozen permissible street designs, most of which are applicable to two or more Transect zones. ${ }^{295}$

Table 1 compares street widths under the Huntsville Code, the Sugar Land Code, and the SmartCode.

TABLE 1: Street width $^{296}$ (in feet)

(minimums listed unless otherwise stated)

Residential or minor streets

Sugar Land local

Huntsville local

26

SmartCode T3 zone

10 (28 maximum, including parking lanes)

Mid-intensity areas

Sugar Land collector

Huntsville com. collector

36 if two lanes, 44 if four lanes

SmartCode T4 zone

36-60 (typical; no citywide minimum)

High-intensity areas

Sugar Land arterial

16 (36 maximum, including parking lanes)

Huntsville arterial

T5 zone

48

36-60 (typical; no citywide minimum)

T6 zone

28 (80 maximum, including parking lanes)

36 (80 maximum, including parking lanes)

The SmartCode tends to favor smaller streets and lanes than the Huntsville and Sugar Land codes. However, the SmartCode also provides builders and municipalities with more flexibility. At all levels of intensity, the SmartCode maximum width is comparable to or higher than the typical street widths of Huntsville and Sugar Land. But by allowing skinnier streets, the SmartCode gives landowners the opportunity to use land for housing, shops, and offices that might otherwise be used for streets.

\section{b) Long Blocks or Short?}

Huntsville also requires that blocks on arterial and collector streets must be at least 1,000 feet long ${ }^{297}$ - not the longest in the United States ${ }^{298}$ but

295. See SMARTCODE, supra note 29, at SC87 tbl.3B (listing various street designs for various zones and noting that different street designs will lead to different amounts of traffic).

296. Street sizes for Huntsville and Sugar Land are taken from notes 272-282, supra and accompanying text, while street sizes for the SmartCode are listed in Table 3B of the SmartCode. Minimums for streets that exist solely as access roads for parking lots (listed at the bottom of Table $3 \mathrm{~B}$ ) are not included in the figures below.

297. See HUNTSVILLE CODE, supra note 146, app. B, art. 4.2.

298. See Robert Campbell, Lively City Neighborhoods Require New Blocks on the Block, BosTON GLOBE, Jan. 13, 1991, at A4, available at 1991 WLNR 1732980 (noting that the city with largest block size, Salt Lake City, has 1200 -foot blocks). 
several times the size of blocks in some other cities. ${ }^{299}$ Sugar Land's regulation of blocks is somewhat less restrictive: Sugar Land requires that blocks be at least 500 feet long ${ }^{300}$ - still longer than the $200-400$ feet blocks that some commentators consider ideal for pedestrians. ${ }^{301}$

Cities with Huntsville-size blocks by definition have fewer intersections per mile ${ }^{302}$ - which means pedestrians have fewer places to cross streets and thus must spend more time trying to reach destinations between two intersections. ${ }^{303}$ By contrast, short blocks (such as the 200 -foot blocks common in Portland, Oregon $)^{304}$ make it easier for pedestrians both to cross streets ${ }^{305}$ and to reach destinations without going out of their way to do so. ${ }^{306}$ Thus, pedestrians benefit from short blocks and suffer from long blocks. ${ }^{307}$

The SmartCode does not set a minimum or maximum block size but does indirectly encourage smaller blocks by setting up a maximum "block perimeter" (that is, the combined length of all blocks at an intersection) ${ }^{308}$ of 2,000-3,000 feet-more in the T3 zone, fewer in the more urban zones. ${ }^{309}$ So the SmartCode allows the creation both of blocks as large as those in Sugar Land and Huntsville and of smaller, more pedestrian-friendly blocks. ${ }^{310}$

\section{c) Cul-de-Sacs vs. Grids}

Both Huntsville and Sugar Land generally require residential streets to be laid out in a cul-de-sac pattern. The Huntsville code provides that local streets must "discourage use by through traffic . . . . A grid system of street

299. Id. (stating Portland, Oregon, has 200-foot blocks).

300. SUGAR LAND CODE, supra note 160, § 5-22(B)(1).

301. See EWING, supra note 80 , at 4 (arguing that 300 -foot blocks are desirable for walkability);

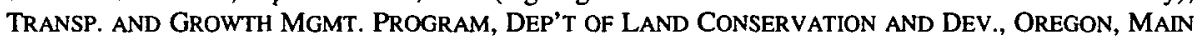
STREET . . WHEN A HighWAY RUNS THROUGH IT 35 (1999), available at http://www.lcd.state. or.us/LCD/TGM /docs/mainstreet.pdf [hereinafter OREGON MAIN STREET] (listing 200-400 feet as ideal).

302. See Campbell, supra note 298 (noting that Portland has "the smallest block size-and therefore the most intersections" of any American city).

303. See Jeff Gray, Police Blaming Accident Victims, Pedestrian Says, Globe \& Mall, Mar. 15, 2004, at A8, available at 2004 WLNR 18380258 (stating that suburban Toronto is "trouble for pedestrians" because of large streets that "barely allow pedestrians enough time to cross and the long blocks that provide so few safe opportunities to do so").

304. See Campbell, supra note 298.

305. See Gray, supra note 303 (longer blocks mean fewer opportunities to cross streets).

306. See Lewyn, supra note 231 , at 1189.

307. Short blocks may also benefit drivers because a street with more intersections per mile gives drivers more chances to visit (and park on) side streets. See OREGON MAIN STREET, supra note 301, at 35 .

308. See, e.g., Greensboro Code of Ordinances $\S 30-6-13.4$ (2006), available at http://www. municode.com/services/gateway.asp?sid=33\&pid=10736 (last visited Nov. 13, 2006) (requiring that in most zones, "block length shall not exceed one thousand five hundred $(1,500)$ feet, for a maximum block perimeter of six thousand $(6,000)$ feet").

309. SMARTCODE, supra note 29, at $\$ 129$ tbl.14 (setting forth maximum block perimeters of 2,000 feet in T5 and T6 zones, 2,400 feet in T4 zone, and 3,000 feet in T3 zone).

310. See HUNTSVILLE CODE, supra note 146, app. B, art. 4.5(2)(c); Sugar Land Paving Design, supra note 280 , div. 6.3.6. 
layout is discouraged."311 Sugar Land sets forth a $300-450$ foot "minimum curvature" for local streets, ${ }^{3 / 2}$ thus implying that a curvilinear, cul-de-sac layout shall be the norm. By contrast, the SmartCode discourages cul-desacs by allowing them only "when [w]arranted by natural site conditions." 313

A cul-de-sac system is not without its advantages: a small street's very lack of connection to the other streets ensures that it will not be clogged with cars. ${ }^{314}$ But on balance, a residential neighborhood composed purely of cul-de-sacs tends to limit walking. In a cul-de-sac subdivision, a cul-de-sac may be connected to a busy collector street-but often, cul-de-sac streets will not connect with other cul-de-sacs nearby. ${ }^{315}$ Thus, residents of a neighborhood cannot visit their neighbors without going out of their way to visit the collector street. ${ }^{316}$

And in cities like Huntsville and Sugar Land, the collector street is often too wide to be comfortably visited or crossed. ${ }^{317}$ Thus, subdivisions composed purely of cul-de-sacs, when combined with uncomfortably wide collector streets, may encourage driving and discourage walking. ${ }^{318}$ It logically follows that the SmartCode's restrictions on cul-de-sacs will make streets more walkable.

\section{Why THE SMARTCODE PRotects Property RightS MoRe EFFECTIVELY THAN CONVENTIONAL ZONING}

Some critics of New Urbanism assert that New Urbanism unduly interferes with market preferences for sprawling development. For example, Ronald Utt of the Heritage Foundation describes the New Urbanism as "a movement . . . that says we should simply force people to live in what certain others have decided is good." 319 This "property rights" attack is highly relevant not just to the political feasibility of New Urbanist zoning ${ }^{320}$ but

311. HUNTSVILLE CODE, supra note 146, app. B, art. 4.5(2)C.

312. Sugar Land Paving Design, supra note 280 ("The minimum curvature for a local street less than two thousand feet $\left(2,000^{\prime}\right)$ long shall be three hundred feet $\left(300^{\prime}\right)$. The minimum curvature for a local street two thousand feet $\left(2,000^{\prime}\right)$ long or longer shall be four hundred and fifty feet $\left(450^{\prime}\right)$.").

313. SMARTCODE, supra note 29 , art. 3.6.2(c), at SC27.

314. See Wendy C. Perdue, Lawrence O. Gostin \& Lesley A. Stone, Public Health and the Built Environment: Historical, Empirical, and Theoretical Foundations for an Expanded Role, 31 J.L. MED. \& ETHICS 557, 562 (2003) ("[W]hen planners propose to eliminate cul-de-sacs and provide through traffic, those who live on the cul-de-sac almost invariably complain that their neighborhood will be less safe and their children will be able to play outside less freely. Thus, the cul-de-sac may offer its own health benefits.").

315. DUANY ET AL., supra note 8, at 23 (adding photo of such a subdivision).

316. See id.

317. See supra notes 286-294 and accompanying text (explaining disadvantages of wide streets).

318. See DUANY ET AL., supra note 8, at 23-24. Moreover, cul-de-sacs may create disadvantages for drivers, in that they increase congestion by forcing cars into a few major streets. See SMARTCODE, supro note 29, art. 3.6.2(b)-(c), at SC27 (explaining that congestion occurs when "cars back up to exit onto the lone collector from a neighborhood").

319. LEVINE, supra note 7, at 11 (noting Utt's assertion that such compulsion is "the main idea of New Urbanism" (quoting Lehrer, supra note 31) (internal quotation marks omitted)).

320. See Joseph L. Sax, Why America Has a Property Rights Movement, 2005 U. ILL. L. REv. 513, 
even to the constitutionality of SmartCode enforcement. The Supreme Court has held that under the Takings Clause of the Fifth Amendment, ${ }^{321}$ the constitutionality of a land use regulation depends in large part "upon the magnitude of a regulation's economic impact and the degree to which it interferes with legitimate property interests. ${ }^{, 322}$ So if a SmartCode provision interferes with property interests to a greater extent than would a similar provision in a conventional zoning code, the more intrusive provision is more likely to constitute a compensable "taking."

But in fact, the SmartCode is less intrusive than conventional zoning in many respects. For example:

*The Huntsville and Sugar Land zoning codes generally prohibit mixing housing and commerce. ${ }^{323}$ By contrast, the SmartCode allows small stores and restaurants in single-family neighborhoods and generally allows larger-scale commerce in its more urban zones. ${ }^{324}$ Thus, a landowner can use his or her land in more ways under the SmartCode than under conventional zoning codes.

*The SmartCode allows a landowner to build fewer parking spaces on his or her land than do the Huntsville and Sugar Land codes. ${ }^{325}$ Thus, a landowner who wants to substitute housing or businesses for parking has more freedom to do so under the SmartCode.

*The SmartCode allows a developer to build narrower streets on his or her land than do the Huntsville and Sugar Land codes. ${ }^{326}$ Less land devoted to streets means more land that can be devoted to building profitable houses, offices, shops, and apartments.

To be sure, the SmartCode adds some regulations not present in the Huntsville and Sugar Land codes, such as restrictions upon cul-de-sacs and maximum setback requirements. ${ }^{327}$ But these regulations do not consistently substitute coercive regulations for the free market. Instead, the SmartCode sometimes substitutes one set of regulations for another (e.g., by substituting grids for cul-de-sacs). ${ }^{328}$ So, from the standpoint of a property rights ideologue, even the SmartCode's most intrusive provisions may be no worse than conventional zoning - but some of its provisions are far better.

513 (noting increasing political strength of "property-rights movement").

321. See U.S. CONST. amend. V (requiring property not "be taken for public use, without just compensation").

322. Lingle v. Chevron U.S.A., Inc., 544 U.S. 528, 540 (2005).

323. See supra notes $146-163$ and accompanying text.

324. See supra note 170 and accompanying text.

325. See supra notes 259-264 and accompanying text.

326. See supra notes 295-296 and accompanying text.

327. See supra notes 252,308 , and accompanying text.

328. See supra notes 306-08 and accompanying text. 


\section{MAKING THE SMARTCODE SMARTER}

As noted above, a primary goal of New Urbanism is to create lively, pedestrian-friendly communities. ${ }^{329}$ However, a few SmartCode regulations actually get in the way of this goal-although not to the same extent as those of Sugar Land or Huntsville. Specifically, the SmartCode's density and parking regulations could be significantly liberalized without harm either to the SmartCode's design goals or to the broader public goal of protecting property rights.

\section{A. Does the SmartCode Allow Enough Density?}

As noted above, the SmartCode provides for gross residential densities of two dwelling units per acre in its suburban zone, four to six units per acre in its intermediate urban zone, and twelve units per acre in its most urban zone. ${ }^{330}$ These densities may not be consistently high enough to support walkable, transit-friendly communities. In only six large American cities (New York, San Francisco, Washington, Chicago, Boston, and Philadelphia) do over one-fourth of commuters use public transit to get to work. ${ }^{331}$ Table 2 shows that each of these six cities is far more compact than most of the zones proposed by the SmartCode.

TABLE 2: Gross density (measured as number of dwelling units per square mile) $)^{332}$

$\begin{array}{ll}\text { SmartCode T3 zone } & 1,280 \\ \text { SmartCode T4 zone } & 2,560 \\ \text { SmartCode T5 zone } & 3,840 \\ \text { Washington } & 4,476 \\ \text { Philadelphia } & 4,900 \\ \text { Chicago } & 5,075 \\ \text { Boston } & 5,202 \\ \text { San Francisco } & 7,421 \\ \text { SmartCode T6 zone } & 7,680 \\ \text { Brooklyn } & 13,183 \\ \text { Manhattan } & 34,756\end{array}$

329. See supra notes $99-100$ and accompanying text.

330. See supra note 195 and accompanying text. But cf. supra note 208 and accompanying text (landowner who utilizes TDRs may build more units per acre than otherwise).

331. See U.S. CEnSUS BUREAU, StatistiCal ABSTRACT OF THE UNITED STATES: 2004-2005, at 695 tbls.1085-86 (124th ed. 2005), available at http://www.census.gov/prod/www/statistical-abstract-2001 _2005.html [hereinafter STATISTICAL ABSTRACT].

332. See CENSUS INDEX, supra note 197 (showing where to find data for individual cities). My figures for the SmartCode zones are derived by multiplying the number of dwelling units per acre allowed in each zone (two in the T3 zone, four in T4, six in T5, and twelve in T6) by 640 (the number of acres in a mile). See Leff, supra note 180, at 1905 (640 acres in a mile); SMARTCODE, supra note 29, at S129 tbl.14 (listing SmartCode density rules). 
To create a city truly friendly to nondrivers, the SmartCode should allow significantly more density in all of its urban zones. ${ }^{333}$ For example, the T4 zone could allow gross densities comparable to those of San Francisco (7,421 dwelling units per square mile, or just over eleven per acre), the T5 zone could allow densities comparable to those of Brooklyn (13,183, or just over twenty per acre) and the T6 zone could allow Manhattan-like density $\left(34,756\right.$, or just over fifty-four per acre).$^{334}$ Instead, the T4 zone provides for only about one-third the density of San Francisco and the T5 zone for about half.

The SmartCode's suburban densities are equally stingy. The T3 zone's proposed density is only $50 \%$ higher than that of Sugar Land, thus ensuring sprawl-like densities. Instead, the SmartCode's suburban zones should be modeled on compact, transit-friendly suburbs. For example, in Bronxville, New York, a homeowner-dominated ${ }^{335}$ suburb of New York City, ${ }^{336}$ over half of all commuters use public transit to get to work. ${ }^{337}$ Bronxville has 2,506 housing units per square mile $\mathrm{e}^{338}$-a density roughly comparable to that of the T4 zone. Other suburbs are even more compact. Lakewood, Ohio, a house-dominated suburb of Cleveland, ${ }^{339}$ has 5,121 housing units per square mile ${ }^{340}$ - quadruple the gross density of the SmartCode's T3 zone. ${ }^{341}$ So a T3 zone could be several times as compact as the SmartCode allows and still be recognizably suburban. To be fair, the SmartCode's drafters intended that its density quotas be easily adjusted. ${ }^{342}$ But the

333. A more radical alternative would be to eliminate density restrictions altogether. Such a strategy would certainly create more compact cities but would make it impossible to use the Transect as a means of creating a diverse spectrum of urban environments (from highest-density to lowest-density). Instead, planners would just have to rely on the market to create dense and not-so-dense environments. A full discussion of such a radical change is beyond the scope of this Article.

334. In fact, some perfectly respectable neighborhoods have even higher densities than the Manhattan average. Jane Jacobs, a commentator who has inspired New Urbanists, points out that many prosperous urban neighborhoods have as many as $\mathbf{2 7 5}$ dwellings per acre and suggests that neighborhood vitality falls off when neighborhoods have fewer than 100 units per acre. See JACOBS, supra note 189, at 217; cf. Stephen T. Del Percio, The Skyscraper, Green Design, \& the LEED Green Building Rating System: The Creation of Uniform Sustainable Standards for the 21st Century or the Perpetuation of an Architectural Fiction?, 28 ENVIRONS ENVTL. L. \& POL'Y J. 117, 128 (2004) (noting that Jacobs's 1961 book The Death of Life of Great American Cities "spawned" the New Urbanist movement).

335. See Bronxville, NY, Houses and Residents, http://www.city-data.com/housing/housesBronxville-New-York.html (last visited Nov. 13, 2006) (noting that only 540 of city's 2387 housing units are renter-occupied).

336. See Mike Gorrell, Snow-Bound, SALt LaKe TrIB., Feb. 17, 2004, at A1, available at 2004 WLNR 11212999 (describing Bronxville).

337. See The Carfree Census Database, supra note 140.

338. See CENSUS INDEX, supra note 197.

339. See Comment, Zoning Ordinances Affecting Churches: A Proposal for Expanded Free Exercise Protection, 132 U. PA. L. REv. 1131, 1133 (1984) (describing Lakewood as "a Cleveland suburb composed primarily of one- and two-family residences").

340. See CENSUS INDEX, supra note 197.

341. See supra note 332 and accompanying text.

342. See SMARTCODE, supra note 29 , art. 3.4, at SC20 (density quotas "allow adjustment according to the site and market conditions"). 
SmartCode sets low density as a default rule, thus encouraging less imaginative planners to prohibit truly compact development. ${ }^{343}$

It could be argued that low-density zoning is necessary to prevent the congestion that comes from packing more people (and thus more drivers) into a city or neighborhood. ${ }^{344}$ But it could just as easily be argued that lower densities may increase congestion by increasing driving: residents of low-density cities and neighborhoods must drive more than other Americans, ${ }^{345}$ thus by definition creating more congestion (other factors being equal). Indeed, less automobile-dependent communities are often less congested than sprawling cities or regions of comparable size. ${ }^{346}$ The New York City metropolitan area has a far higher public transit ridership than any other American region ${ }^{347}$-yet New York City has less congestion (measured by annual delay per traveler) than ten of the twelve largest American urbanized areas. ${ }^{348}$ By contrast, the most congested American region (Los Angeles $)^{349}$ has relatively low transit ridership. ${ }^{350}$ So if the SmartCode al-

343. See supra notes 330-333 and accompanying text.

344. See, e.g., Schenck v. City of Hudson, 997 F. Supp. 902, 905 (N.D. Ohio 1998) (upholding city zoning ordinance because city "has the right to limit the density of population to prevent congestion"), aff'd, 208 F.3d 215 (6th Cir. 2000); City of Bellevue v. E. Bellevue Cmty. Council, 983 P.2d 602, 608 (Wash. 1999) (holding city could reasonably conclude "that of possible densities, the lowest would be better given existing severe traffic congestion in the area").

345. See supra notes 192-194 and accompanying text.

346. See STATISTICAL ABSTRACT, supra note 331, at 695 tbl.1085.

347. See id. (stating $24.9 \%$ of commuters in New York metro area used public transit; no other metro area had over $12 \%$ transit market share). This measure of transit ridership differs from the measurements of city ridership discussed above, see supra note 331 and accompanying text, in that includes commuters in suburbs as well as cities. See Gillham, supra note 4, at 18 (metro areas include cities and their suburbs).

348. David Schrank \& TIM Lomax, TeXas TransP. INST., The 2005 URBan Mobility RePORT 12 tbl.1 (2005), available at http://tti.tamu.edu/documents/mobility_report_2005.pdf (noting that New Yorkers had forty-nine hours of annual delay per traveler-lower than ten of the other twelve urbanized areas listed as "very large"). Note, however, that the other urbanized areas showed no clear pattern: of the more transit-friendly large regions, some (such as San Francisco and Washington) had unusually high levels of congestion while others did not. Id.; see also STATISTICAL ABSTRACT, supra note 331, at 695 (listing public transit "market shares" for various cities and regions).

349. StATISTICAL ABSTRACT, supra note 331, at 693 tbl.1083. Because Los Angeles and its suburbs are more densely populated than other regions, it could therefore be argued that Los Angeles's congestion problems prove that density increases traffic congestion. See Michael Lewyn, Sprawl, Growth Boundaries and the Rehnquist Court, 2002 UTAH L. REV. 1, 43-44 (describing argument). But this argument lacks merit for three reasons. First of all, the correlation between regional population density and congestion is quite weak. Id. at 44-45 (containing table listing densities of twenty-one most congested regions; of the seven regions on the list with over 3,000 people per square mile, only Los Angeles was one of five most congested, and only Los Angeles and Washington were among ten most congested). Second, Los Angeles's generally high level of density masks the fact that it lacks a dense, transit-friendly core. See SHOUP, supra note 218, at 654 (central city of Los Angeles far less compact than those of New York and San Francisco). Third, Los Angeles's enormous amount of parking encourages driving and thus congestion. $I d$. at 164 ( $81 \%$ of downtown Los Angeles land area consumed by parking lots). So, Los Angeles's combination of density and congestion may be related to minimum parking requirements that encourage driving and thus prevent its high density from encouraging walking or transit ridership. Id. at 165; see also supra notes 231-249 and accompanying text (explaining how minimum parking requirements encourage driving and discourage other forms of transportation).

350. See STATISTICAL ABSTRACT, supra note 331, at 695 tbls. 1085 \& 1086 (4.7\% of Los Angelesarea commuters, and $10.2 \%$ of residents of city of Los Angeles, used transit to reach jobs; by contrast, comparable percentages for New York City were almost $25 \%$ for region and over $50 \%$ for city, and comparable percentages for other relatively transit-friendly regions such as Boston and Philadelphia 
lows densities high enough to reduce automobile dependency, it is possible that it might create less congested environments than does conventional zoning.

In sum, the SmartCode's density requirements allow only modest liberalization of conventional zoning's density-phobia. But if the SmartCode allowed landowners to build truly compact neighborhoods, it could give landowners the best of both worlds: more pedestrian and transit-friendly places and the expansion of freedom that occurs when landowners can use their land without bureaucratic interference.

\section{B. Parking: Freedom First, Parking Second}

The SmartCode, like conventional zoning, requires landowners to provide parking for visitors and customers. ${ }^{351}$ The SmartCode's parking regulations are less harmful to street life than those of other cities because the SmartCode encourages landowners to place parking lots in the middle or rear of buildings rather than in front of those buildings. ${ }^{352}$ Thus, the SmartCode discourages the "strip mall effect" ${ }^{353}$ that results when parking lots surround buildings.

But even the SmartCode's relatively lenient parking rules have two of the same harmful side effects as other parking regulations. First, all minimum parking requirements reduce density by reducing the number of housing units or places of employment that a landowner can place on a parcel of land, ${ }^{354}$ thus increasing automobile dependence. ${ }^{355}$

Second, by increasing the supply of parking, minimum parking requirements make parking free or nearly so, ${ }^{356}$ thus subsidizing driving, ${ }^{357}$ thus increasing traffic congestion and increasing the political pressure for the sort of anti-density regulations common in conventional zoning codes. ${ }^{358}$

An obvious solution to the ills of minimum parking requirements is simply to abolish such regulations and allow the free market to regulate parking. Abolition would give landowners more freedom to respond to changes in the demand for parking, and if landowners used such flexibility to place housing on land now used for parking lots, parking deregulation would make cities more compact and pedestrian-friendly.

Planners justify minimum parking requirements as a means of avoiding "cruising" (i.e., motorists driving slowly through streets searching for park-

were $8-9 \%$ for metropolitan area and $25-33 \%$ for city).

351. See supra notes 257-258 and accompanying text.

352. See supra notes 265-266 and accompanying text.

353. See Lewyn, supra note 231, at $1183-84$ n.82 (quoting Mason, supra note 231 (using term))

(internal quotation marks omitted).

354. See supra notes 237-239 and accompanying text.

355. See supra notes 192-194 and accompanying text.

356. See supra note 242 and accompanying text.

357. See supra notes 243-247 and accompanying text.

358. See supra note 344 and accompanying text (noting that anti-density restrictions are often justified by concerns about traffic congestion). 
ing, thus creating additional congestion). ${ }^{359}$ But this cost of the free market may well be outweighed by the costs of minimum parking requirements, such as a reduced supply of housing and businesses (and thus a higher overall cost of living) and increased automobile dependence. ${ }^{360}$ To the extent that minimum parking requirements are "fertility drugs for cars," cally follows that such regulations may actually increase traffic congestion by encouraging driving.

It could be argued that drivers' demand for parking is so inelastic that the abolition of minimum parking requirements would have no effect on parking demand (thus leading to parking shortages and cruising). ${ }^{362}$ This argument is of questionable validity for two reasons. First, there is some evidence from other contexts that demand for driving is in fact elastic-if driving becomes more expensive or alternatives to driving become less expensive, the demand for parking will fall. For example, when a group of Silicon Valley employers offered employees free transit passes, the demand for parking declined by $19 \%^{363}$ - despite the fact that parking was still free ${ }^{364}$ and the cost of a transit pass $(\$ 420 \text { per year })^{365}$ is far less than the benefit of free parking to employees (roughly $\$ 127$ per month, or about $\$ 1,500$ per year). ${ }^{366}$ Similarly, mass transit ridership increased throughout America in 2005 when gasoline prices spiked. ${ }^{367}$

Second, the demand for parking might be even more elastic in a "SmartCode city" than in a typical American city or suburb because the SmartCode seeks to create an environment where residents can easily walk or use mass transit to most destinations. ${ }^{368}$ By contrast, in a typical American city or suburb, most residents must drive everywhere to perform even the simplest tasks and thus need more parking than they would in a more pedestrian-friendly city. ${ }^{369}$ So even parking requirements that make sense in

359. See Stroud v. City of Aspen, 532 P.2d 720, 723 (Colo. 1975) (en banc) (deferring to city's position that minimum parking requirements are justified by public interest in preventing cars from "moving slowly around block after block seeking a place to park . . clog[ging] the streets, air and ears of our citizens").

360. See supra notes 232-249 and accompanying text.

361. Cyndee Fontana \& Jim Wasserman, Are We Over-Paving Paradise?, Fresno BEE, July 16, 2000, at A1, available at 2000 WLNR 1721654 (using phrase).

362. This argument assumes, of course, that the abolition of minimum parking requirements would cause businesses to use space for housing or commerce that would otherwise be used for parking. It may be that businesses would provide parking in order to satisfy customers even if they were not required to do so by government. If so, abolition of minimum parking requirements would do little good and little harm as well.

363. See SHOUP, supra note 218 , at 254.

364. Id. at 253 .

365. Id. at 252

366. See id. at 213 tbl.7-4.

367. See Press Release, Am. Pub. Transp. Assoc., High Gas Prices, Emerging Technologies Spur Transit Ridership Increases (Sept. 26, 2005), http:/www.apta.com/media/releases/documents/050926gas _prices.pdf (citing numerous examples).

368. See SMARTCODE, supra note 29 , art. 1.2.2c, at SC5-SC7 ("[O]rdinary activities of daily living should occur within walking distance of most dwellings, allowing independence to those who do not drive.").

369. See Lawrence M. Friedman, The Eye That Never Sleeps: Privacy and Law in the Internet Era, 
Sugar Land or Huntsville might not make sense in a jurisdiction covered by the SmartCode.

And even if demand for parking was not significantly affected by the abolition of minimum parking requirements, less restrictive regulatory alternatives could reduce or eliminate cruising. For example, cities could charge market rates (i.e., rates high enough to eliminate shortages) ${ }^{370}$ for onstreet parking, thus reducing cruising by ensuring that people who value parking the least would drive less or park far from their destinations rather than competing with other drivers for the most convenient free parking spaces. ${ }^{371}$ Or cities could institute "residential parking permit" districts reserving on-street parking for residents and their guests, thus preventing commuter parking (and thus cruising) from affecting residential blocks. ${ }^{372}$

\section{CONCLUSION}

In Huntsville and Sugar Land, as in much of America, zoning law promotes automobile-dependent sprawl through:

*single-use zoning that separates residences from shops and offices, thus making it difficult for Americans to live within walking distance of housing, work or shopping;

*density limits that force homes and apartments to consume more land than a free market would dictate, thus artificially increasing the distance between housing and commerce;

*setback and parking regulations that force landowners to surround buildings with parking lots, thus subsidizing driving while making pedestrian visits to apartments, shops, and offices longer and more unpleasant than necessary; and

*street design regulations that make streets too wide and too long for pedestrian comfort.

All of these regulations interfere with both pedestrians' interests in more walkable communities and landowners' interests in doing what they like with their own land, thus reducing economic freedom and raising the cost of doing business.

40 TULSA L. REV. 561, 563 (2005) ("[F]or almost every adult outside of a few large central cities—the automobile is an absolute necessity.").

370. For example, a city could raise parking meter prices, reducing demand enough that each block remains only $15 \%$ empty and every driver willing to pay could thus find a parking space. See Matt Smith, Remote Controlled, S.F. WKLY, Aug. 17, 2005, available at 2005 WLNR 15278044 (in July 2005, Redwood City, California recently enacted such a system).

371. See SHOUP, supra note 218 , at 297-301, 379-90 (describing mechanics of such a system). To make more expensive parking politically feasible, cities could spend revenue from on-street parking on public services in the neighborhood that generates such parking revenue, thus giving neighborhoods an incentive to support parking meters. Id. at 397-400.

372. See County Bd. v. Richards, 434 U.S. 5,7 (1977) (upholding such a system against equal protection challenge). Apparently, parking permit systems are quite effective in deterring spillover parking. See SHOUP, supra note 218, at 433-34 (suggesting that parking permit system is too effective to be efficient; by eliminating spillover parking entirely, permit systems ensure that many parking spaces are unused). 
The SmartCode mitigates the problems caused by these regulations by allowing landowners to build mixed-use neighborhoods with narrow, walkable streets. Thus, the SmartCode is preferable to the status quo from a New Urbanist perspective-and often from a libertarian perspective as well.

But the SmartCode could be even smarter in some respects: that is, the SmartCode is sometimes insufficiently radical in its response to sprawlgenerating land use regulations. In particular, the SmartCode should do more to deregulate density and should eliminate minimum parking requirements altogether. By allowing the market to regulate density and parking, the SmartCode would enhance both walkability and property rights. 
